\title{
EXPLORATION AND RESPECTATION OF THE SPATIAL STRUCTURE OF CITIES, TOWNS, TOWNSHIPS AND VILLAGES AS A SIGNIFICANT FORMANT OF THEIR IDENTITY
}

\author{
Liucijus DRINGELIS ${ }^{a}$, Evaldas RAMANAUSKAS ${ }^{b}$, Ingrida POVILAITIENĖc, \\ Justina MAČIUKĖNAITÉ ${ }^{d}$ \\ Institute of Architecture and Construction of Kaunas University of Technology, \\ Tunelio g. 60, LT-44405 Kaunas, Lithuania \\ E-mail: aliucijus.dringelis@ktu.lt, bevaldas.ramanauskas@ktu.lt (corresponding author), \\ ci.lipnickyte@gmail.com, djustina.maciukenaite@gmail.com
}

Received 25 November 2014; accepted 9 March 2015

\begin{abstract}
Under the conditions of globalization and integration the issue of identity preservation with respect to the spatial structure of the Lithuanian cities, towns, townships and villages has been discussed by many authors. The need to protect the originality and identity of landscape in the countries of the world, their natural and cultural heritage, the spatial structure and architecture of the cities, towns, townships and villages under such complicated circumstances is considered in a number of national and international documents. On the basis of the carried out indoor research and field exploration the paper aims at the discussion of the most significant urbanistic, architectural, landscape and other features that form the specificity and identity of the Lithuanian cities, towns, townships and villages. The following specific features of the settlements have been analysed: the period when a settlement emerged, its visual interaction with the environment (panoramas, silhouettes), natural conditions (terrain line, water bodies, green spaces), plan and spatial structure (street network, building arrangement, squares, green spaces, etc.) and significant buildings (sacred, public and other buildings and constructions). Due to their significance and uniqueness all the mentioned features form the identity of the analysed object. The following objects were selected for the research: all towns (103), townships (249), church villages (301), villages as local administrative centres (97) and ordinary villages with adequate natural and cultural heritage (318), in all 1.068 settlements, or $5 \%$ from the total number of the country's settlements (21.043).

On the basis of the carried out research, the paper analyses the historical development of Lithuanian cities, towns, townships and villages; the current demographical and urban status of the country's settlement system; defines the principles of settlement selection and identity research methods; discusses the research progress and the results obtained during the exploration of the specificity of the spatial structure of cities, towns, townships and villages. The analysis of the spatial structure of the country's largest cities has also been presented which reveals the violations of their most specific features (e.g. old towns, river valleys, etc.). The paper also offers a comparative analysis of the specificity of Lithuanian cities, towns, townships and villages and adequate types of settlements in foreign countries.
\end{abstract}

Keywords: specificity of the settlements, spatial structure, identity research, specific components, landscape.

\section{Introduction}

The specificity of the spatial landscape structure of the country's (as well as of its particular ethnic regions) cities, towns, townships and villages, its significance for the preservation of national identity has been widely discussed and written about. This relevant problem has been approached from various perspectives by the scholars representing diverse fields of enquiry historians, philosophers, ethnographers, art critics, architects, etc. Important international and national documents have been adopted on the mentioned issue.

Due to globalization and integration, a vital need to protect the originality of the countries' landscape all over the world, its identity, natural and cultural heritage, the spatial structure and architecture of the cities, towns, townships and villages has been pointed out in the majority of international documents 
of the European Council, UNESCO and ICOMOS charters, conventions, declarations and recommendations, among which the following documents might be considered: the Convention for the Protection of the Architectural Heritage of Europe (Granada 1985), the European Convention on the Protection of the Archaeological Heritage (Valeta 1992), the Convention concerning the Protection of the World Cultural and Natural Heritage (Paris 1972), the European Charter of the Architectural Heritage (Amsterdam 1975), the European Urban Charter (Strasbourg 1992) and especially the European Landscape Convention (Florence 2000). The latter acknowledges that the protection, provision and planning of the landscape make an extremely relevant problem in the context of entire Europe. Alongside with the above mentioned international papers an important national document, the resolution Landscape Policy of the Republic of Lithuania (Vilnius 2004) should be also taken into consideration. All of them do clearly confirm the relevance of the analysed problem.

The paper aims to define the most significant natural and anthropogenic elements of the spatial structure of the Lithuanian cities, towns, townships and villages and their characteristics since they determine the originality and specificity of the country's settlements in comparison to the characteristics of the settlements of other countries and regions.

In order to achieve the mentioned aim the following tasks have been set out: to gather and systematize the information about the Lithuanian cities, towns, townships and villages, thei number, size and arrangement; on the basis of the worked out methods to make a selection of the settlements to perform the indoor research and field exploration; to carry out the field exploration of the selected objects and summarize the obtained results; to perform a comparative analysis with the adequate data presented by the neighbouring countries. The course of the performed tasks, the applied methods and obtained results will be described in the adequate sections of the paper.

When discussing the investigation of the specificity of the spatial structure of the Lithuanian cities, towns, townships and villages it should be noted that this relevant issue has been considered by a number of authors analyzing the problems of architecture, urbanistics, landscape and the like. However, the exhaustive studies focussing on the peculiarities of the designed spatial structure of the Lithuanian living localities in comparison to the adequate characteristics of the similar objects in other countries have nearly not been offered. In most cases, the above mentioned problems are fragmentally touched upon in urban or architectural rese- arch. Village peculiarities are revealed in the works of K. Šešelgis and M. Urbelis (1980) and K. Šešelgis (1988) focussing on the old Lithuanian village design, architecture and landscape. Rather widely village landscape, its historical evolution and heritage are discussed in the works of J. Bučas $(1988,2001)$. Yet, here the issue of the specific identity is only briefly introduced alongside with other analysed subjects. Some issues related with the spatial structure of the old Lithuanian villages are partially considered by M. Purvinas (2011 a, b, 2013). The historical evolution of the Lithuanian cities and towns, their designed and spatial structure and cultural heritage were exhaustively researched and described by A. Miškinis (1991, 1999, 2002, 2004, 2005, 2007, 2009). The architecture of the urban landscape as a significant component of a city's identity was comprehensively analysed by K. Jakovlevas-Mateckis $(2008,2011,2014)$. The issue of the specificity of recreational architecture was discussed by V. Stauskas (2012), G. Daniulaitis (2001, 2003), P. Grecevičius and R. Marčius (2006) and others.

Alongside with the mentioned works that more or less fragmentally introduce the issue of the originality of the Lithuanian cities, towns, townships and villages the following scientific works devoted to the discussion of the identity and specificity of the city of Vilnius should be taken into consideration. Firstly, the monograph "Vilniaus miesto vizualinio identiteto apsauga ir pletros principai (Protection of the Visual Identity of the City of Vilnius and the Principles of Its Development)" by Z. J. Daunora, S. Kirvaitiene and A. Vyšniūnas (2004) should be introduced. This work focuses on the need to investigate and preserve the identity of the city of Vilnius, enhance its image, also initiating the analysis and protection of the specific identity of any city, town, township or village. The authors claim that such an initiative requires the improvement of the legal basis for territorial planning which would lay down the requirement that alongside with the preparation of the general plan of a settlement the investigation of its specificity and identity should be carried out and its protection provided.

Another publication analysing the urban identity of the city of Vilnius in the collection of papers "Vilniaus miesto savitumai (The Specific Features of the City of Vilnius)" (2006). The paper written by A. Mačiulis (2006) argues that the principal factors determining the specificity of Vilnius are natural environment and its characteristics as well as the city's urban architectural structure, its urban silhouette and panoramas. The author maintains that the most distinct feature of Vilnius is a harmonious interaction between natural environment and architecture. Other scholars of the 
selected papers approach the peculiarities of the city of Vilnius from various perspectives: D. Bardauskiene (2006) extends an urbanistic aspect, J. Vanagas (2006) is interesred in the problem of the city in relation to its territorial expansion, J. M. Daujotaite (2006) discusses the impact of the natural morphostructure of Vilnius on its urban identity, etc.

The architectural heritage of the city of Vilnius and its specific characteristics have been widely discussed by V. Drema in his fundamental study "Dingęs Vilnius (Lost Vilnius)" (1991).

The problem of the identity of the city of Kaunas is analysed in the paper "Kauno miesto identiteto formantų išsaugojimo galimybès planuojant miesto vystymąsi (Possibilities for the Presentation of the Identity Formants of the City of Kaunas in Planning the City's Development)" by K. Zaleckis, J. Kamičaitytè-Virbašiene and E. Ramanauskas (2013). Here the symbols forming the city's urban identity are distinguished - natural symbols (the river Nemunas and the river Neris, their hillsides, Oak Wood, etc.); functional symbols (The Old Town, The New Town, the morphostructure of their arrangement, fortresses, etc.); iconic signs (Town Hall, Cathedral, Christ's Ressurection Church, The Pažaislis Camaldolese Monastery Complex, etc.); conventional signs (the places of collective gathering, communication, entertainment or national holiday celebration, etc.). The authors claim that these and other symbols that form the city's identity should be analysed and respected in the general plan of Kaunas.

The urban development of the Klaipeda city, its architecture and identity have been exhaustively described in J. Tatoris' book "Senoji Klaipeda (Old Klaipeda)" (1994). The isues of urban identity are discussed by V. Rubavičius (2005), A. Samalavičius (2013), J. Minkevičius $(2005,2014)$, V. Petrušonis $(2002,2010)$, R. Čepaitienè (2006) and others. The urban image of the city, its specificity and identification in relation to its exceptional objects or elements are considered by the scholars of other countries: K. Lynch (1960), G. Cullen (1961), Ch. Alexander (2002), N. A. Salingaros (2006), C. Moughtin (1999), etc. The history of the European cities was researched by L. Benevolo (1998) and others.

Due to a diversity of approaches regarding the specificity of the Lithuanian cities, towns, townships and villages, in their analysis of the spatial structure, the authors of the given paper have accepted the most common background of estimation, i.e. the type of plan of the settlement which contains the street network, square arrangement, the system of green plantation spaces and the like. After having considered the 'common denominator' as the basic factor for systematic evaluation, other spatio- structural elements have been added and evaluated - such as housing, housing height, significant buildings and constructions, their spaces, panoramas, silhouettes and the like, whose variety and quantity determine the individuality and specificity of each settlement.

To determine the type of the plan of an urban area an already existing division (see Miškinis 1991) of the towns into four major types, a linear, radial, rectangular and mixed, has been employed. To determine the type of the plan of a village an already offered division of the villages into stack type irregular villages, street strip villages, street homeyard villages and individual farms (see Butkevičius 1971) has been applied. Some rural settlements, i.e. townships, church villages and the Soviet design settlements of the collective farms demonstrate a more complex arrangement and hence have the type of the plan similar to that of a town. Since the variety of the plans of the Lithuanian cities, towns, townships and villages as well as their possible variants may be rather large, the most typical and significant representations have been discussed in relation to their specificity.

On the basis of the above mentioned background for the estimation of specificity the paper discusses the spatial structural components of the selected cities, towns, townships and villages, the whole complex of which determine the specificity and individuality of these settlements. To describe their identity, firstly, the authors consider the carried out complex field exploration during which the observation of the analysed objects in place was made, their photo fixation and the description of the field investigation done and other necessary information gathered. The carried out research allowed at least partially survey the present state of the spatial structure of the Lithuanian cities, towns, townships and villages, its alterations that most often acquire a negative character and offer some suggestions for the preservation of their spatial structural identity under globalization conditions.

Since the terms specificity and spatial structure are frequently used in the paper, it is reasonable to define them. Specificity is a multifaceted concept that might be understood as identity, individuality, originality, uniqueness, traditionality (in ethnoculture), authenticity (in cultural heritage), etc. Generally, the following definition has been accepted: specificity is a set of anthropogenic and natural features that might identify the unique features of cities, towns, townships and villages, in other words, their identity. Spatial structure is defined as a three-dimensional system that helps to express the compositional housing peculiarities of cities, towns, townships and villages as well as of their parts. 


\section{The historical evolution of the settlements of the Lithuanian cities, towns, townships and villages and their present state}

\section{The historical evolution of the Lithuanian cities, towns, townships and villages}

The concept of landscape embraces two major components: a natural component (land, forests, water bodies, etc.) and an anthropogenic component (cities, towns, villages, various buildings, engineering constructions, etc.). The interaction between these components and their functional, compositional, aesthetic and other connections determine the type of the lanscape, its specificity and identity. To a certain extent, the alterations within one component cause the alterations within the other component that may be either positive and harmonious or negative, producing a negative impact on the entire environment.

No doubt, the most rapidly changing and most active are the anthropogenic components of the landscape - the settlements of towns and villages whose formation and growth directly depend on the social, economic, political and other factors. Therefore when discussing the historical development of the Lithuanian cities, towns, townships and villages, their expansion and alterations, it is important to analyse the particular historical periods and their political and economic conditions that determined a different character of the landscape and cultural heritage. Hence when planning and re-arranging the settlements, it is vital to explore, respect and preserve the typical peculiarities of the landscape's spatial structure of each period.

As the historical data claim, the earliest dwellers and their primitive dwellings appeared in the territory of Lithuania around 11.500-10.000 years ago (see Basalykas 1977). About 2.500 years ago with the population growth and development of agriculture, in the forest territories, the scattered settlements, the population camps, fortified farms, etc. were built. According to A. Basalykas (1977), until the beginning of the $12^{\text {th }}$ century the network of Lithuanian settlements represented four types: feudal castles, fortified villages of barons and open scattered villages of field cultivators. Some fragments of such settlements have remained until today. These are first and foremost the locations of the former castles that eventually initiated the early beginning of the towns; the fortified villages of the barons and field cultivator's farms later on turned into what is today known as village settlements.

It might be said that approximately up to the beginning of the $16^{\text {th }}$ century the development of the Lithuanian living locations was of spontaneous character. Yet small, scattered non-economical land plots and villages hampered the development of agriculture, the formation of the settlements and economic growth. Therefore from about the middle of the $16^{\text {th }}$ century the Law of the Valakas Land Reform initiated by the monarch Sigismundus Augustus in 1557 started the land reform, during which attempts were made to introduce land management, land use and its registration to improve the economic situation of the State. The reform brought a new design of the street strip villages, the towns of a rectangular shape and introduced new requirements in their planning. The Valakas Land Reform was the result of the significant and pioneering state landscape planning and provision which reflect the period's social, economic and cultural conditions and the specificity of its cultural heritage.

Furtheron, with the change of the country's political and economic conditions under the Russian Tsar's rule marked by the growth of towns and formation of villages, the need arose to perform another land reform related with the division of the villages into individual farms. Such division was carried out in the Tsarist Russia at the beginning of the $20^{\text {th }}$ century (the socalled Stolypin Land Reform of 1906-1914). Yet in the mentioned period this reform did not reach a wider scale in Lithuania.

The major division of the former villages into individual farms started in the Independent State of Lithuania in 1922 under the land reform initiated by the priest prelate M. Krupavičius. This reform was one of the most progressive in Europe at that time. The principles of social justice and vital interests of the growing Lithuania served as its basis. It had a high state, historical, social and economic significance. After its performance, an underdeveloped serfdom country grew into a rapidly developing modern State.

Unfortunately, this period was very brief. The occupation of Lithuania by the Soviet Union brought a new reform known as collectivisation that started in 1945. Small private farms were destroyed and large agricultural units known as collective farms (or kolkhozes) and state farms were formed. In the place of individual farms, the new Soviet style settlements appeared. They were also established in new territories. The Soviet Land Reform initiated the construction of large productional complexes, livestock farms and other objects. Alongside with the described land reform the industrialization of the country was carried out. The development of industry determined the rapid growth of towns. New districts and microdistricts were built in the cities which contained the industrial houses of silicate bricks and large-block constructions. It had completely changed both the landscape and the cityscape of the country, its design and spatial structure, the panoramas and silhouettes. This period, as well 
as other historical periods has left the particular traces in the country's landscape and threfore they may be considered as the specific characteristics of the mentioned time.

With the regain of independence and the alteration of the political, social and economic conditions in Lithuania the vital need for the reforms arose causing a new land reform based on the elimination of large collective farms and erection of individual farms. However, similarly to the interwar period, the planned land reform has not been fully carried out. It was limited to restoring the land to the former owners by also introducing the so-called "land movability", when the piece of land in one area could be replaced by another one in a desired location. It caused chaos in land exploitation since the land reform was not properly worked out. It complicated the development of the settlements, constructions of engineering communications and the usurpation of the valuable natural and recreational territories. This process still continues at present although serious attempts have been made to control it with regard to the public interests of the society and other factors.

While estimating the historical development and alterations of the lanscape's spatial structure it should be noted that these alterations were mainly caused by the period's political, social and economic conditions determining the adequate land reforms. Thus, from the middle of the 16th century the country has experienced five major land reforms, the four of them taking place in a historically short period, i.e. in a single century. Each of the discussed reforms has left rather distinct traces in the Lithuanian culture, landscape, cityscape and architecture. That is why the cultural heritage of each historical period should be considered as a part of the country's specificity and originality to be respected and protected.

\section{The present system of the country's settlement} and its urban and demographic state

In order to determine and discuss the specific features and identity of the spatial structure of the Lithuanian cities, towns, townships and villages, first and foremost, it is vital to discuss the present state of the settlements, their territorial arrangement, number, size, status, demographic situation, etc. This data, on the basis of the statistic analysis of the results of the general census of the population and dwellings in Lithuania carried out by the Department of Statistics of Lithuania in 2001 and 2011 are presented in the paper of L. Dringelis (2013) devoted to the investigation of the impact of the demographic and urban changes in the Lithuanian cities, towns, townships and villages on the country's spatial structure.
The mentioned paper claims that in the present period due to the administrative division of the territory of Lithuania, there are 10 regions, 60 municipalities ( 7 city municipalities, 43 district municipalities, 10 local municipalities) and 513 smallest administrative territories, the so-called elderships. There are 103 towns and cities and 20.940 rural living areas. There are four cities (with more than 100.000 population), 29 mid-size towns (from 10.000 to 100.000 population) and 70 small towns (from 3.000 to 10.000 population). Rural living areas encompass 294 small towns (from 500 to 3.000 population), 19.004 villages (including church villages, having up to 500 population) and 1.687 units of so cold settlements of single farm. Yet it should be stressed that a great part of townships (more than $50 \%$ ), although still having the status of the town do not reach the standard of 3.000 population as it is determined in the law of the territorial administrative units and their boundaries in the Republic of Lithuania. There are villages where the number of the population exceeds 3.000. Moreover, due to the shortcomings found in the country's administrative territorial division, the statistical data does not include such settlements as Nida, Juodkrante, Preila and Pervalka which make the part of the Neringa town. The same should be noted about the Šventoji and other settlements included into the town of Palanga.

When discussing the urban and demographic state of Lithuania it should be stressed that it is rather complicated. During the last decade (i.e. from 2001 to 2011) the number of population decreased by 440.000 or $12.46 \%$. Alongside with the marked demographic changes the significant urbanistic alterations occured: cities and towns decreased in their status, some villages and individual farms became deserted, or got entirely vanished. For instance, during the mentioned period the county lost three towns (the number decreased from 106 to 103), among them one city (4 left out of 5), five mid- size towns (the number decreased from 34 to 29), which descended to the level of small towns. The number of the villages decreased significantly: 838 villages vanished ( 4\%; their number decreased from 19.842 to 19.004$) ; 48$ settlements of so cold single farm disappeared ( $3 \%$; from 1.735 to 1.687).

The mentioned alterations have a high negative impact on the country's inhabitation system, distribution of settlements, their density, spatial structure of the landscape, natural environment, etc. Therefore it is vitally important to investigate the present state of the Lithuanian cities, towns, townships and villages, their design and spatial structure and natural environment to determine their specificity and characteristic features and offer suggestions regarding their preservation. 
Analysis of the specificity of the spatial structure of the country's cities, towns, townships and villages

\section{Settlement selection for research and identification of their specific features}

After having distinguished the common number of the Lithuanian cities, towns, townships and villages the next step is to perform their selection for the specificity research, since it is impossible to examine all the settlements; the more so that for such type of investigation the field or natural exploration of the chosen objects must be carried out. With respect to the significance of the country's settlements, their status, cultural and natural heritage and their reachability, the visibility and other factors, for the initial examination, the following preliminary units have been chosen: all the cities and towns (103), townships (249), church villages (301), villages as centres of the elderships, or sub-districts (97) and villages possessing objects of natural and cultural heritage (318). In total, 1.068 settlements, or $5 \%$ from the total number (21.043) (Fig. 1). To examine the mentioned objects, the features necessary to define them have been determined. The following major features have been considered: the status of a settlement, the number of population, the period of its establishment, the visible interaction with the environment (panoramas, silhouettes), natural conditions (terrain line, water bodies, green plantation spaces, etc.), design and spatial structure (plan type, street network, building arrangement, height, squares, etc.), important buildings (sacred buildings, mansions, public buildings and constructions). The whole complex of the mentioned features, their significance and uniqueness to a certain extent reveals the specificity of the analysed object and its identity.

The analysis of the specificity of the settlements and its estimation may have various perspectives: the pers-

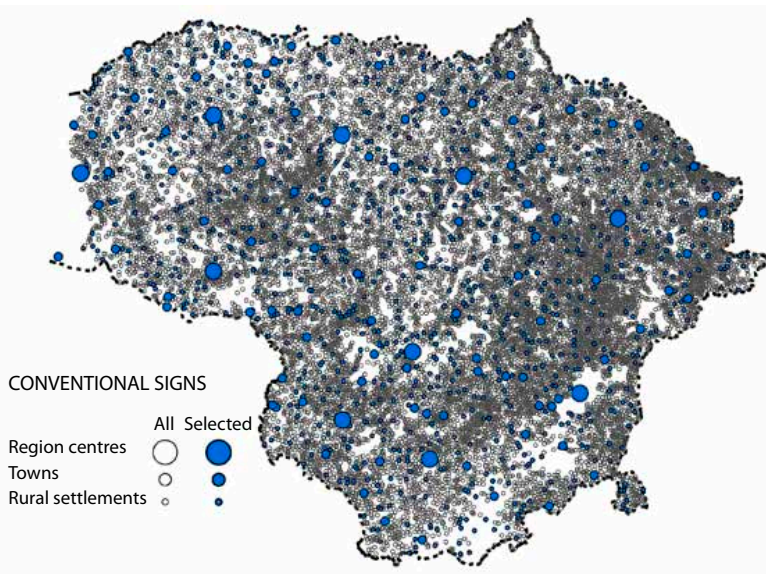

Fig. 1. Settlements of Lithuania and their selection for the research of spatial structure pective of the specificity of the spatial structure, the perspective of natural conditions and landscape uniqueness, the perspective of cultural heritage and tradition, etc. In order to ascertain the public opinion about the object's originality (i.e. how the society or community perceive the specificity of a particular settlement) and what components (natural and anthropogenic) participate in its formation, the sociological survey has been carried out. Such sociological analysis of the specificity of the spatial structure of the Lithuanian cities, towns, townships and villages was carried out by the Market and Opinion Research Centre "Vilmorus" under the order and worked out programme of the Institute of Architecture and Construction at Kaunas University of Technology.

The representative survey of the Lithuanian inhabitants was carried out at the end of 2013 by questioning 1.000 respondents whose age was 18 years old and above. The type of survey was an interview at the respondent's home; the method of selection was the stochastic model of multilevel selection. It was carried out in five biggest cities of Lithuania - Vilnius, Kaunas, Klaipėda, Šiauliai, Panevèžys, in the Druskininkai urban resort and in nineteen districts. In total, the exploration was made in 20 towns and 30 villages. As the summary of the questionnaire results claims, the majority of the inhabitants gave the following answers to the question What makes the specificity of the spatial structure of the city, town, township or village you live in?: churches (47.9\%), parks (44.2\%), water bodies (rivers, lakes, ponds) (3.2\%). Slightly less significant were the following components: panoramas (38.3\%), street networks (30.1\%) and squares (27.9\%). To sum up the discussed results, it may be claimed that the inhabitants of the settlements estimate the significant elements of the spatial structure of their area by more or less uniformly distinguishing both the representative sacred buildings (churches) and natural objects (parks, water bodies, etc.). The discussed representative professional sociological analysis of the public opinion survey supplements and expands the range of the carried out research of the spatial structure of the settlements and grants greater objectivity.

On the basis of the performed selection of the settlements for the research and possessing the particular components of their investigation and estimation (i.e. natural and anthropogenic) some results regarding the analysis of the specificity of the spatial structure of the cities, towns, townships and villages have been presented. They have been obtained by in-door research (survey of scientific literature, archives data, orthographic and other material) and field or natural exploration (field exploration inventories, photo fixation, visual observation and the like). 
Summary of the research of the features of the settlements' spatial structure

Having preliminarily defined the total number of the selected town and rural settlements (1.068 settlements) the exploration in place of the part $(\sim 60 \%)$ of the cities, towns, townships and villages was carried out (Fig. 2). The summary of the obtained results is given in Table 1. On the basis of this data it has been determined that the major part of the explored Lithuanian towns $(\sim 80 \%)$ were built during the period of the Grand Duchy of Lithuania (i.e. the $13^{\text {th }}-18^{\text {th }}$ centuries); around $8 \%$ of the towns date back to the Tsarist period; about $1 \%$ of the towns originated in the interwar period and about $6 \%$ were erected in the Soviet period. A somewhat similar situation has been found in the context of villages. The greatest part of the explored villages $(\sim 60 \%)$ date back to the times of the Grand Duchy of Lithuania, especially the old street strip villages associated with the Valakas Land Reform (see Butkevičius 1971). Other villages were formed in the Tsarist period ( 10\%) and Soviet period ( $9 \%)$.

In relation to the emergence period of a settlement, its development and size, the formation of the planned spatial structure of a city, town, township or village is determined; the worked out models are presented in Figures 3 and 4. The simplest type of design is a linear one which is typical of the old Lithuanian villages, townships and partially of small towns. Their spatial structure is most often filled with 1-2 storey wooden or brick dwelling houses that look buried in greenery. The silhouette or panorama of the church villages and townships is additionally enriched with the volumes of the churches and the vertical lines of their towers which make a significant component of the spatial structure of the country's landscape. In most cases, the type of radial plan was formed when $2-3$ roads from the neighbouring areas led to a single

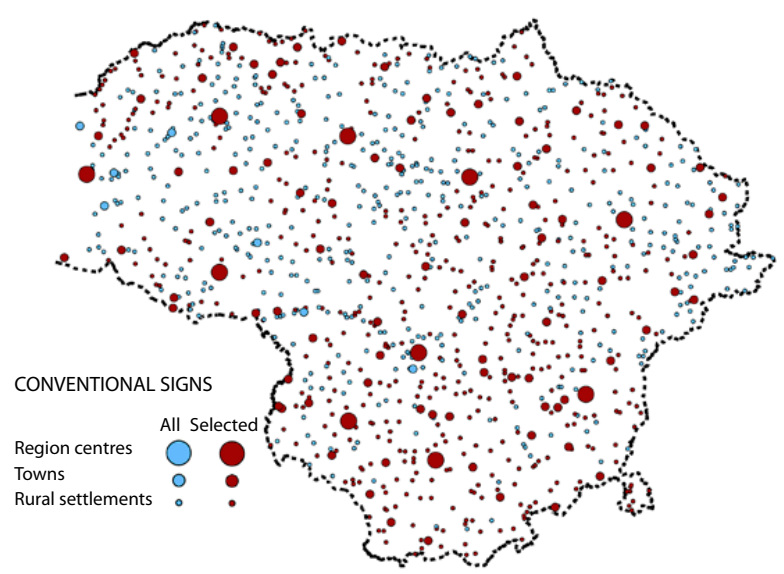

Fig. 2. The country's settlements selected for the research of spatial structure and explored in place

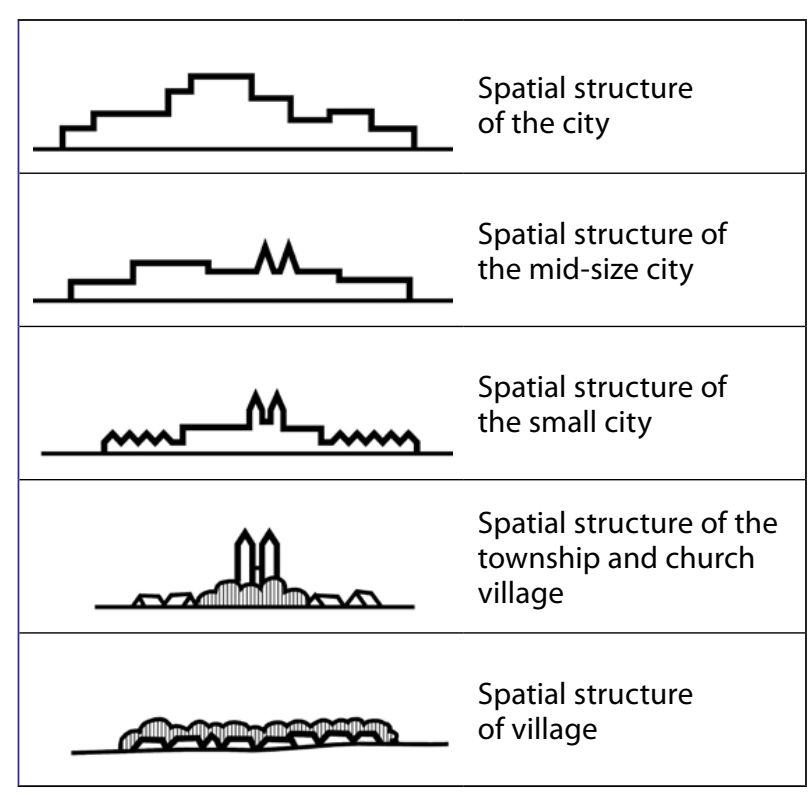

Fig. 3. Models of the spatial structure of the Lithuanian settlements

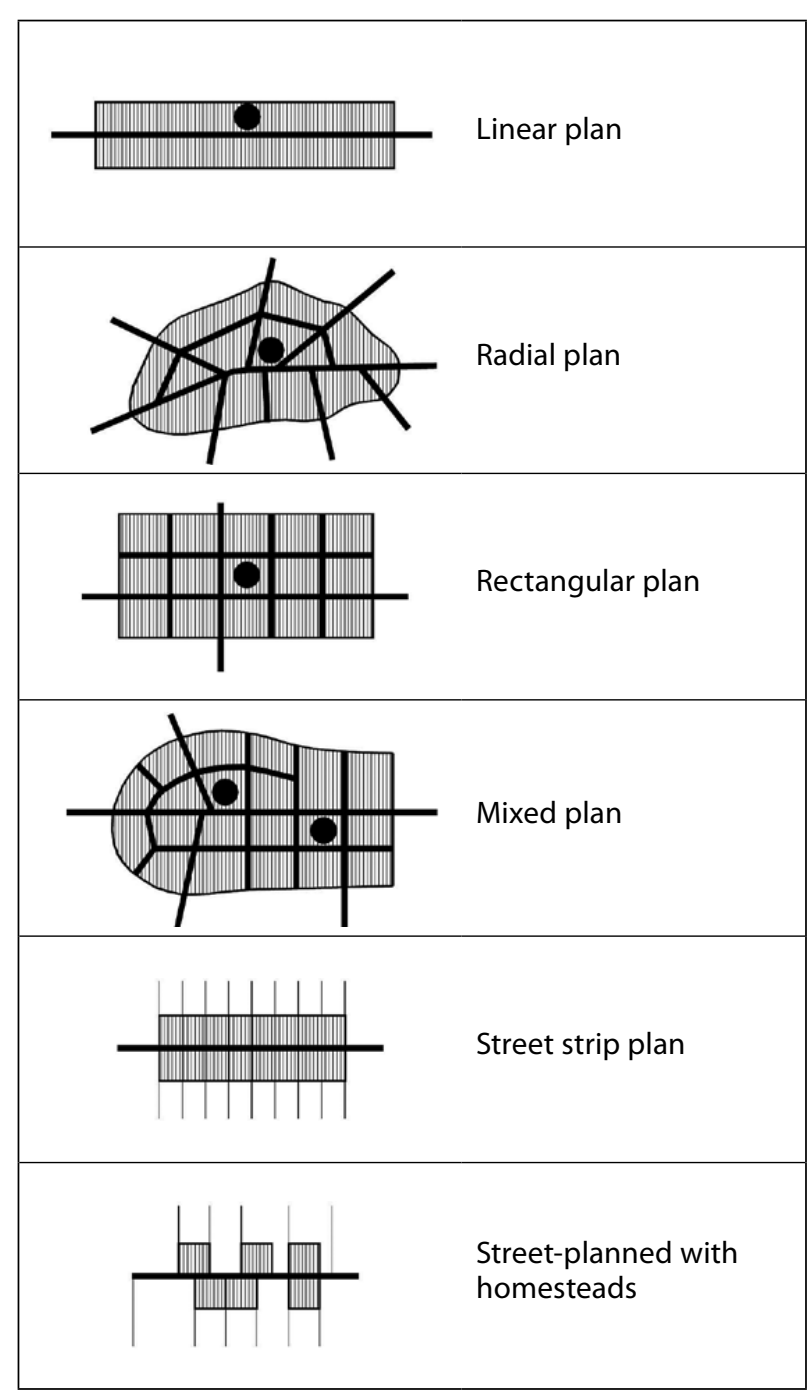

Fig. 4. Plan types of the settlements 
Table 1. The results of the analysis of the spatial structural features of the Lithuanian cities, towns, townships and villages

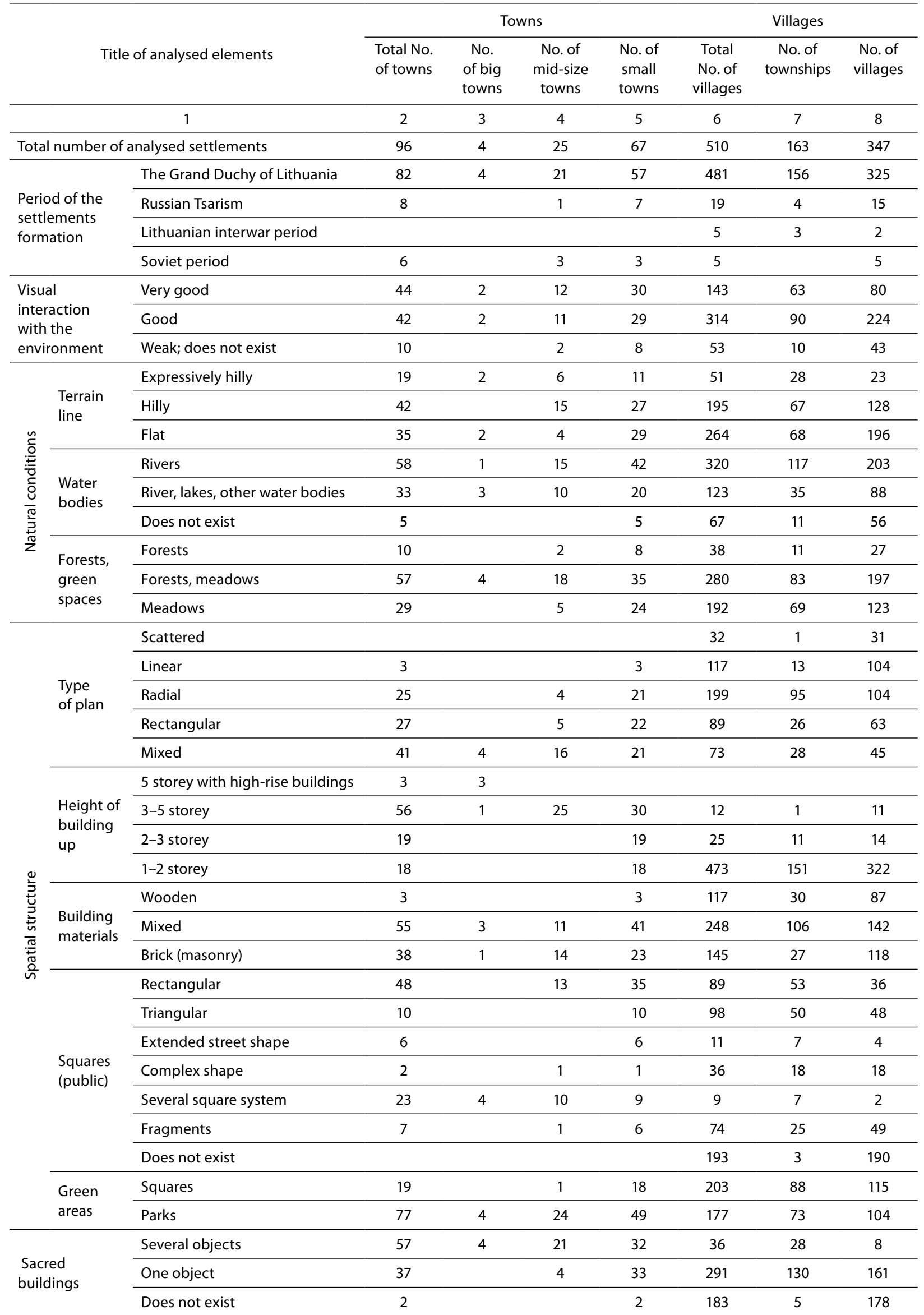


important object (castle, mansion and the like). This type has been rather widely spread both in urban and rural settlements. The rectangular plan is the result of the urban design of the settlements and dates back to the period of the Valakas Land Reform, when towns, townships and villages were designed by following very strict rules. The same might be said about the later and the present periods. The majority of the settlements are of mixed plan (above $40 \%$ ), when one urban structure contains the elements of all the types of planning. This type of design is most widely spread in the midsize towns and cities. To sum up, it might be claimed that the height dominating in the Lithuanian cities is 4-5 storeys, with the groups of high-rise buildings; the dominating height of the mid-size towns is $3-4$ storeys with the groups of multi-storey buildings; the dominating height of small towns is $2-3$ storeys; the prevailing height of townships is 1-2 storeys and the dominating height of village houses is 1 storey.

What concerns natural conditions, it should be noted that nearly all the Lithuanian settlements are located near water bodies. The majority of the cities, towns, townships and villages are located near rivers and streams ( 50\%); a slightly smaller number near the lakes $(\sim 30 \%)$; a rather small number of towns are located on the seaside or near the lagoon; the rest are built near the ponds and brooklets. The forests and relief also play a significant role in the context of the specificity of the spatial structure. The carried out research showed that nearly half of the Lithuanian cities, towns, townships and villages have an expressive or hilly terrain line; the forest mass surrounds around $20 \%$ of the settlements.

The analysis also showed that to some extent nearly each of the explored objects has its specific features. Some objects are unique due to natural conditions, others due to the plan structure and building arrangement, still others due to unique architectural ensembles, historical and archaeological heritage and so on. It may be claimed that in the majority of cases the most valuable are the objects that have a greatest number of identity forming features.

\section{Respectation of the specificity of the settlements' spatial structure during the process of urban development}

On the basis of the summarized research results, several specific features of the spatial structure and the degree of their respectation during the process of urban development in particular Lithuanian cities, towns, townships and villages or their groups are further discussed in the paper. These questions are analyzed by following an accepted sequential order of settlement subdivision into town settlements (i.e. cities, mid-size towns, small towns) and rural settlements (i.e. townships, church villages and villages). In addition to this large scale subdivision by status and size, there is a small scale subdivision by the most common basic feature, i.e. the type of plan. As mentioned above, due to the diversity of the settlements' spatio-structural features (e.g. natural conditions, planning, housing type, etc.) the four types of plan have been distinguished: linear, radial, rectangular and mixed. It has been determined that the plan of a settlement most vividly reflects its period, evolution and other specific features.

Due to the limited space, the authors only briefly discuss the largest Lithuanian cities and a few more significant mid-size and small towns. The specificity of townships and villages is only fragmentally reviewed. By describing these objects, an attempt has been made to reveal both positive and negative experience related with identity protecting and cherishing or absence of the mentioned approaches.

\section{Lithuanian cities}

Regarding the cities, it should be stressed that all the four Lithuanian cities with more than 100.000 population - Vilnius, Kaunas, Klaipeda and Šiauliai, belong to the group of the oldest towns in Lithuania (dating back to the $12^{\text {th }}-13^{\text {th }}$ centuries) with their unique character and do not resemble each other from the natural, urban, or architectural perspective. For instance, Vilnius is a unique city both in Lithuania and the world. This fact was confirmed by the UNESCO which announced that the Old Town of Vilnius is the object of world cultural and natural heritage (1994). Thus, its exceptional value was recognized from the historical, artistic, scientific, aesthetic and other aspects. The specificity of Vilnius and its components has been approached from various perspectives by many authors. All the authors agree that the originality of the city of Vilnius is created by the perfect harmony between the natural (the rivers of Neris and Vilnia, their valley, surrounding hills, green spaces, etc.) and architectural (Baroque style) components. On the other hand, a highly significant role in the context of the city's uniqueness is played by such original semantic objects as, for instance, the Hill of Gediminas with the castle tower, Cathedral with a belfry, the Town Hall with its square and others. Unfortunately, as they claim, the harmony is being destroyed by new, not well thought over constructions that are too close to the Old Town and visually overshadow the city's urban silhouette and panorama. Figure 5 gives the most distinct examples where the "forest" of high buildings visually destroys 
the fragile silhouette in the bridge spatial area with the dominant towers of the Church of St Raphael, the Archangel, or the massif of the residential buildings that overshadow the unique design of the Neoromantic castle, etc. Similar examples with the negative impact on the spatial structure in the Lithuanian cities and towns are more than several.

In order to estimate the impact of the mentioned and other modern constructions on the quality of the environment a particular methodology was worked out, the basis of which contains the principles of environment perception formulated by $\mathrm{Ch}$. Alexander (2002) and expanded by N. A. Salingaros (2006) that allowed to describe the aesthetic value of an object's view. Such methodology concerns the regularities defining the relationship between the elements' size, shape, building arrangement, etc. One of the most important aspects of the method is the distinction of the so-called compositional fields which Alexander calls "centres" and the estimation of their interaction. Such compositional centres are perceived as homogeneous areas of the observed view whose distinction depends on their distance, size, integrity and the like. According to him, the objects which are aesthetically attractive have different scale levels, their size differs about 2-3 times. To

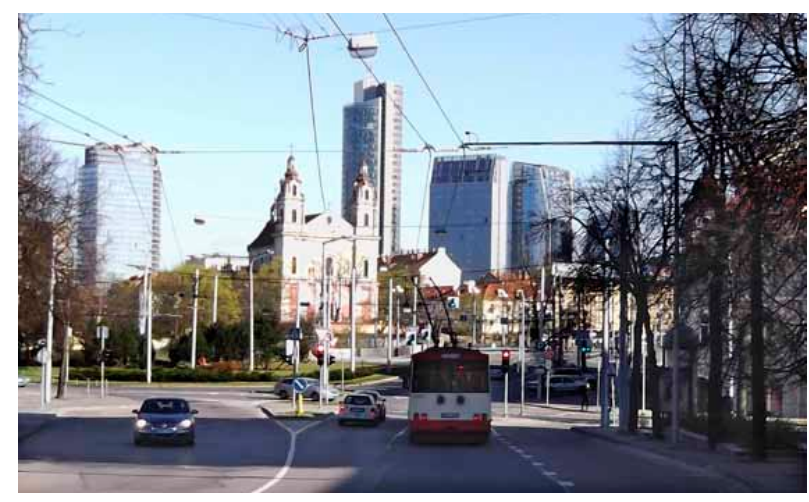

Fig. 5. Collision of the old and contemporary architecture in the city of Vilnius. Located too close to the objects of old architecture different scale modern buildings start overshadowing them from many perspectives (photo L. Dringelis) define the above mentioned relation, Salingaros offers a scaling ratio approximately equal to $e=2.7$. The ratio occurs in the natural shape and physical phenomena and therefore is acceptable to the viewers while perceiving the visually grasped environment.

When estimating the new administrative and office centre that emerged in Konstitucijos avenue with the historical buildings of the city located nearby, the distinct differences in the scale level of the old and contemporary buildings have been observed. The historical buildings (churches, etc.) show a larger range of the scale levels which might be equalled to 2.7 times interval defined by Salingaros (or Alexander's 2-3 times interval). Meanwhile, the range of the scale of the new modern constructions definitely lacks the intermediate scale levels. With regard to its silhouette, the volume flats of the new buildings from the side of the Old Town are perceived as the elements of the higher scale level - in their shape, they are 3-5 times higher than the volume flats of the old buildings and therefore overshadow the old buildings by occupying a dominant position (Fig. 6). It may be noted that from the majority of the formed common perspectives of the old and contemporary buildings, the new buildings due to their large shape and the lack of adequate scale levels (especially when compared with the old vertical lines) often have a negative effect on the Old Town's compositional integrity. Due to their large size they intervene into the space of the city's old part and thus take over the role of a more significant compositional centre. Eventually, under the impact of such new compositional centres some old buildings become their constituent part rather than the opposite, thus losing their significance and identity.

What concerns the specificity of the city of Kaunas, it should be maintained that the major and most important feature is its location on the riverside of the two largest rivers of Lithuania. Its unique natural environment contains the riverside valley with green slope banks and water bodies. It is situated on the confluence of the two rivers. The so-called New Town has a highly

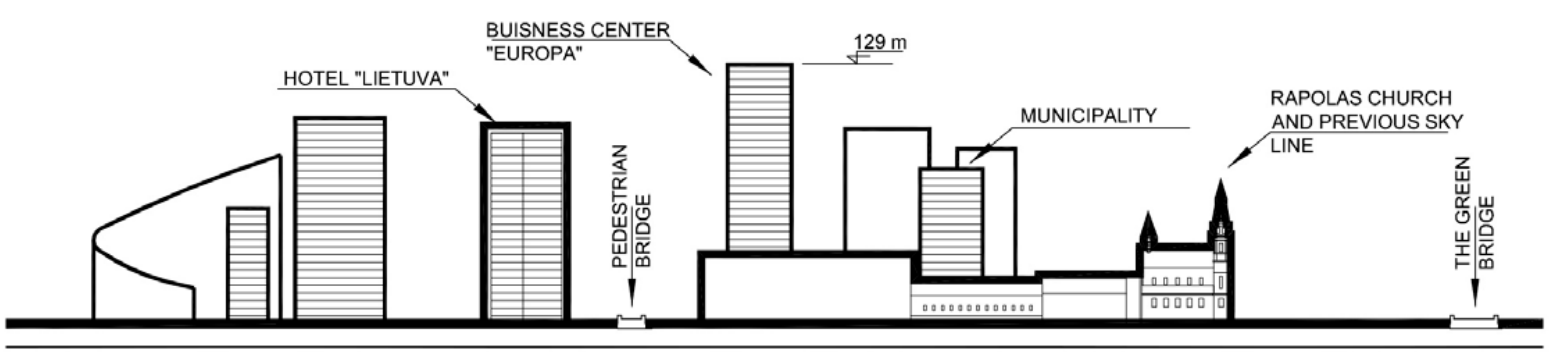

Fig. 6. Due to its height, the complex of Vilnius high-rise buildings overshadows the historical ensemble of the church by diminishing its scale and hence minimising the visual impact on the space of the river Neris valley. 
valuable Modernist interwar architecture. Such semantic signs as the Town Hall located in the central Old Town square, the War Museum Palace and Christ's Resurrection Church make the city easily recognizable in Lithuania and among other cities of the world. Regretfully, the city's government does not properly consider the unique natural conditions which create its originality. For instance, the riverside of the Nemunas river, or in other words, Karaliaus Mindaugo avenue is overcrowded with traffic instead of being used for recreation. New constructions started to be built on the Nemunas Island and other green spaces of the city. The Acropolis shopping centre with its garages above the Karaliaus Mindaugo Avenue and the Žalgiris Sport Arena on the Nemunas Isle are the most distinct examples (Figs 7-10). The emergence of the mentioned objects in such places initiated many discussions from the landscape, urban, functional, traffic organization, aesthetic and other perspectives, embracing the preservation of the Nemunas Valley scale, the Old Town's visual zone and its violation, etc. The majority of the specialists - architects, urban experts, landscape architects, nature experts and public representatives did not support such decisions, but the aggressive commercial business with the help of some concerned specialists and other influential persons had overcome the barrier

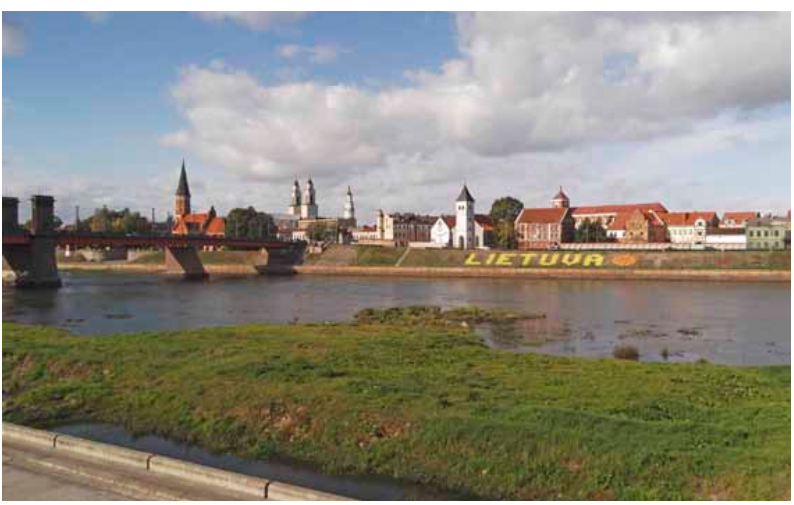

Fig. 7. The Old Town of Kaunas is the city's "visiting card". L. Dringelis photo of the public opinion and became the "winners". An especially obvious example of the priority of the material commercial element over the spiritual and sacred ones, which dominates in our country, is the case of the architectural ensemble of the Carmelite Church of the Holy Cross of the $17^{\text {th }}$ century located in the neighbourhood of the large commercial centre "Acropolis". The former has turned into an insignificant, little visual value possessing supplement to the modern shopping complex. The emergence of these and similar objects has provoked diverse discussions among the society members and professionals.

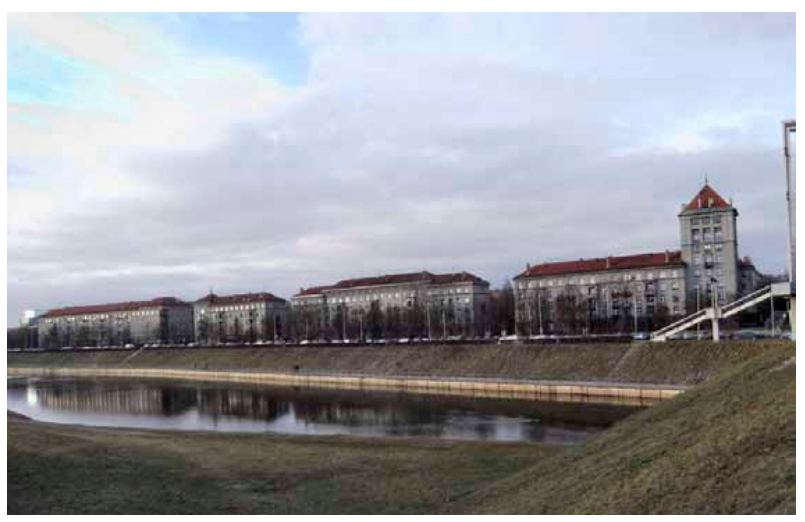

Fig. 8. The formation of King Mindaugas avenue in the city of Kaunas in the middle of the $20^{\text {th }}$ century. L. Dringelis photo

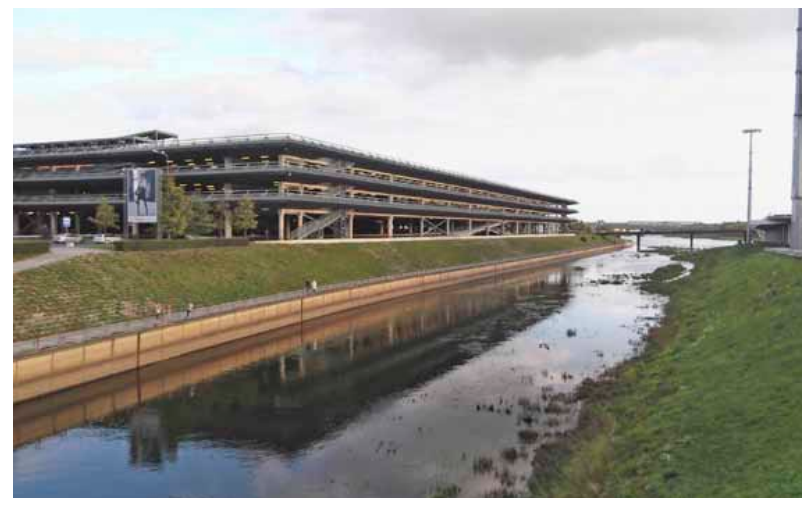

Fig. 9. The formation of King Mindaugas avenue with the multi-storey garage complex in Kaunas at the beginning of the 21st century. A completely unattractive riverside area was created in the city centre. L. Dringelis photo

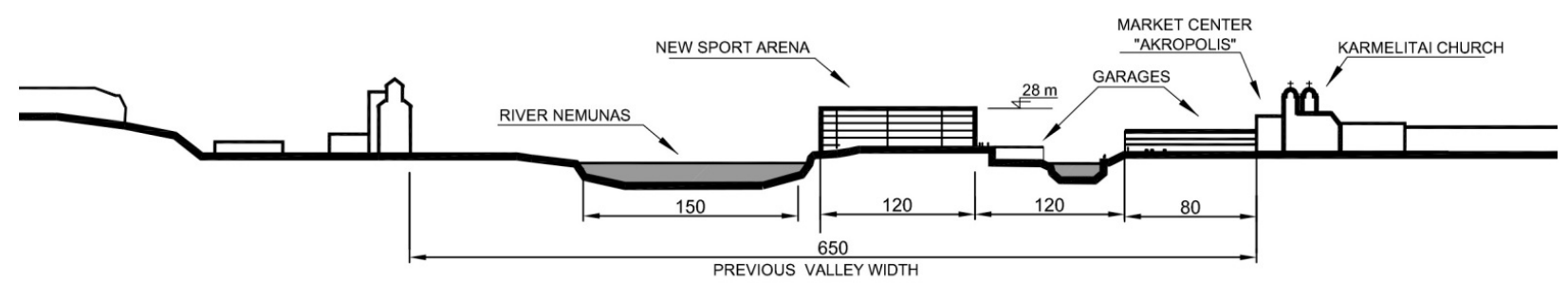

Fig. 10. The space of the river Nemunas valley in Kaunas has lost its integrity when the multi-storey garages and the sport arena were built; the building constructions have altered the scale of the river space by visually diminishing it 
Aiming to estimate the environment created by this shopping centre more objectively the above discussed methodology worked out by Alexander and Salingaros was applied. During the conversion of the former industrial territory, the volumes of the new buildings were detached from the gate of the churchyard, but extended up to the Nemunas riverside. Thus the church was covered from the sight when observed from the Nemunas Valley. The dominant role was taken by the garage construction which essentially destroyed the unique character of this area. This multi-storey construction, being 5-7 times longer than the surrounding buildings has broken the psychologically acceptable rhythm of construction arrangement and the compositional contact with the existing buildings, and thereby created an unacceptable environment for pedestrians. Contrariwise, a pedestrian-friendly environment would be especially welcome in the parts of spaces near the Carmelite Church of the Holy Cross and on the river banks.

Another object in this territory that has a negative effect on the image of Kaunas is the Žalgiris Arena. Despite the fact that it is located on the island, apart from other riverside buildings, the difference between the size of this object and that of the elements of the old riverside building arrangement is more than obvious. The range of the arena's scale is considerably smaller and that is why its large integral volume blocks the perception of other old buildings (the Kaunas elevator, the riverside buildings, etc.). Compositionally, due its large scale the arena seems to be more attached to the mentioned nearby located multi-storey garage complex. Thus it forms a completely new complex of large volumes in the river valley. The newly built constructions diminish and divide the entire space of the Nemunas Valley, blot the sloppy banks and thus destroy a harmonious interaction between the natural and man created components of the landscape thus denying one of the most important conditions necessary for the formation of the identity of the city's spatial structure.

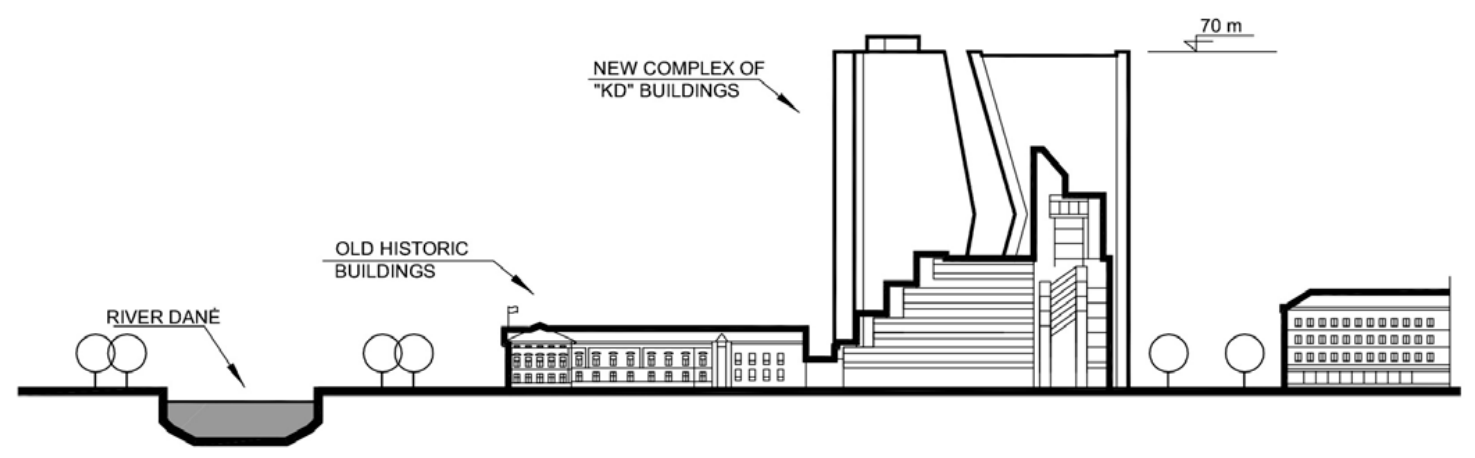

Fig. 12. The complex of the KD buildings in Klaipeda was built near the old houses and thus overshadowed them by creating a relatively hypertrophied scale background
Another city under consideration is Klaipeda which was widely described by J. Tatoris in his book "Senoji Klaipeda (Old Klaipèda)" (1994), revealing its origin, urban evolution and architecture. The author claims that the city was built by the Livonian Order as a town fortress on the coast of the Curonian Lagoon and near the river Dane. Its function determined the following specific features: the castle, the Old Town, the city's planned and spatial structure, architecture, German urban style, etc. Yet with time the city has lost its distinct silhouette marked by the vertical lines of the towers. A new vertical line appeared aiming to give to the city another specificity. Most probably, that was the reason for building a new complex of buildings popularly known as the KD to symbolically represent the city of Klaipeda. Such a straightforward exposure of the city's name by the shape of the buildings is artificially provoked, too formal and therefore disputable, despite the fact that it really serves as a particular semantic sign. Nevertheless, with the use of the mentioned method of estimation, the visual analysis of these buildings in relation to the environment showed that these buildings are out of accord with the city's urban environment and scale (Figs 11, 12).

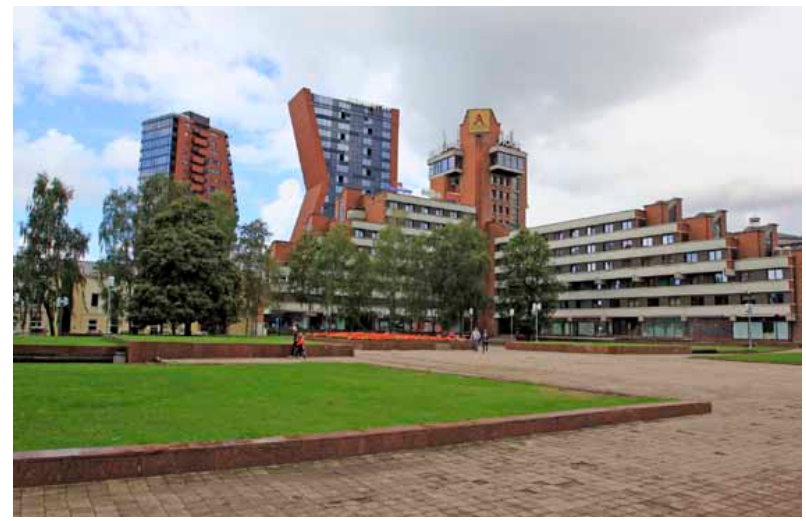

Fig. 11. The new sign of Klaipeda's urban identity is the "KD" building complex. Although it has a significant visual impact on the existing central part of the city, yet the latter's image is not positively enhanced by such composition of volumes. E. Ramanauskas photo 
The complex of the buildings in the shape of the letters $\mathrm{K}$ and $\mathrm{D}$ is clearly distinct by its size and a rather moderate number of scales. In fact, it possesses two levels - the level of small scale elements, which in the close environment are 7-10 times larger than those of the old buildings distinguished in the general view of the city and the large scale elements which differ from the small elements of the same building about 8 times (when an optimal step between the levels of different scale is 2.7 times). These buildings integrated into the city's silhouette are several times larger than the verticals of the Old Town, yet they do not support the compositional interplay of the existing steeples but, contrariwise, seem to overshadow them. It is also important to stress that in the vertical axis the volume shape of the $\mathrm{K}$ and $\mathrm{D}$ buildings has discrepant and contradicting directions when compared with the traditional forms of the existing Old Town buildings which determined the absence of mutual harmony. With such shape directions the buildings are more concordant and acceptable in the background of the Klaipeda port's cargo-carrying cranes.

Šiauliai is the fourth city of Lithuania due to its size. It may be called the city of the lakes. One of them, the lake Talša is located in the central part of the city and is well interacting with the city centre, its central square thus forming a memorable and original urban space. The tower vertical of the church is the dominant of this peculiar urban space and of the whole city, which at the same time serves as a semantic sign of the city.

However, it is important to mention that when forming the housing of main Šiauliai public space of the Resurrection Square, the new building has raised beside the church which weakened and visually destroyed its architectural, compositional and semantic value (Figs 13, 14). The building by representing pretentious, poor, pseudo-modern architecture, discords not only with the volume of the neighbouring church, but also with the entire housing style of the square. It seems that while designing this building neither the neighbourhood of the church, its contextual claims, nor the scale of housing and the square space have not been considered. Accordingly, it might be concluded that both in Šiauliai and other settlements, the most important, semantically loaded objects and the neighbouring surroundings affected by them must be especially respected and preserved.

\section{Mid-size towns}

Beside the mentioned cities there are 29 mid-size towns (having more than 10.000 population). Since the range of the number of the population in the mid-size towns is very high (from 10.000 to100.000) therefore the character of the towns included into this group and their planned and spatial structure, arrangement and other components vary. For instance, due to the decrease of population the city of Panevèžys as the centre of the region and district, formally might be considered as having lost the status of the city, yet it still preserves the character of a large Lithuanian town

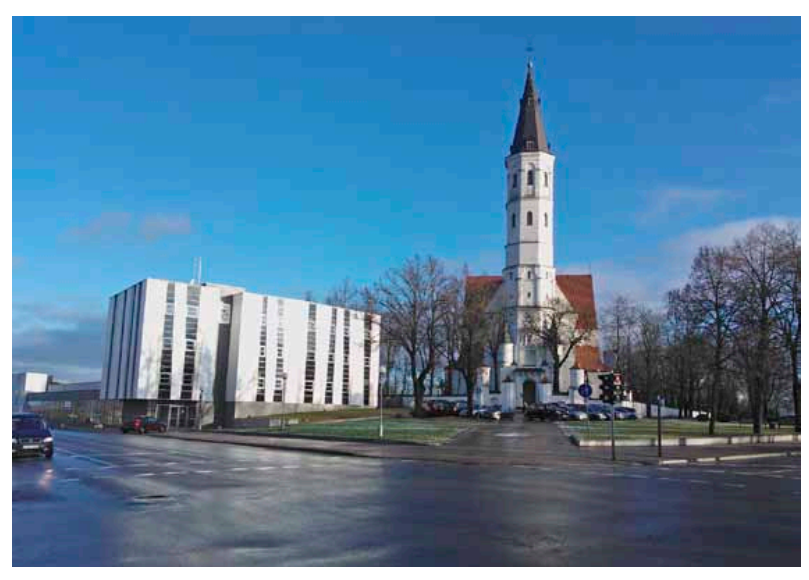

Fig. 13. The church tower is a distinct semantic sign of the urban identity of the city of Šiauliai, but the new building with its architectural forms, scale and size diminish its significance. E. Ramanauskas photo

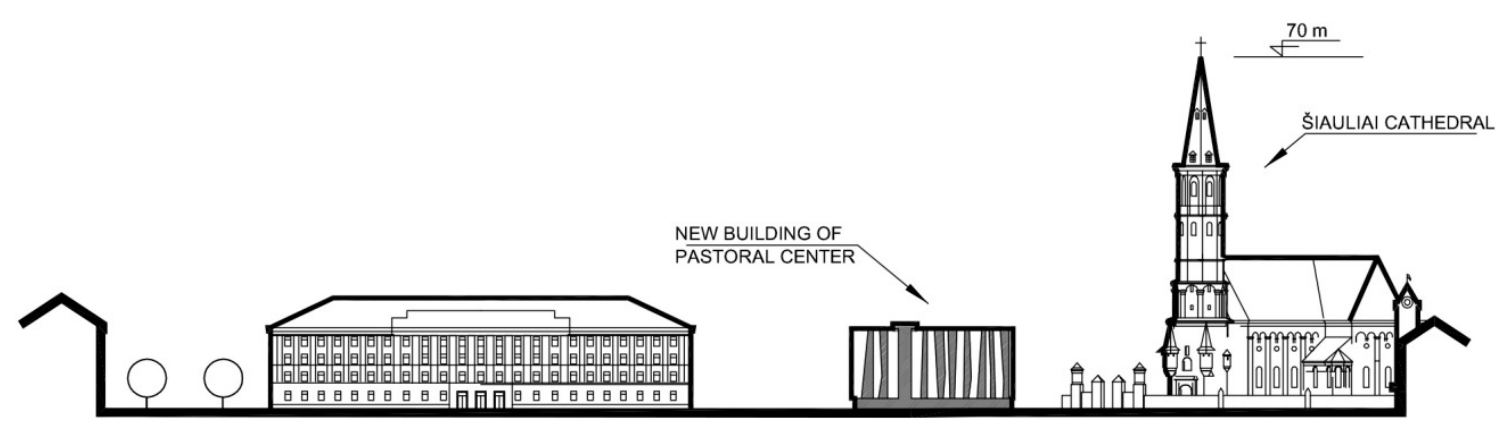

Fig. 14. A new building of the Pastoral Center of the Šiauliai major square broke the former harmony due to its pretentious architecture 
with a specific street network, building arrangement, objects of cultural heritage, organization of the public spaces, natural conditions, etc. It is an old city that was built in the $13^{\text {th }}$ century, traditionally located near one of the largest rivers of Lithuania named Nevèžis, whose planned and spatial structure encompasses the radial street network, the square system and church dominants (Fig. 15).

The Nevezzis old riverbed public space is especially significant in Panevėžys since it joins the central town square, is abundantly visited by the population and thus forms the town's identity and originality.

Other towns of the same group, functioning as the district centres, i.e. Alytus and Marijampole, also considerably differ from other mid-size towns for having greater population, more developed spatial structure and other elements. When discussing the cultural heritage preservation and its use to form a town's spatio- structural specificity, the reorganization of the block in the old town of Marijampole might be considered as a negative example. Here, into the interior space of the old town, near the church, a new "temple" of the shopping center "Maxima" was squeezed in and destroyed the former structure of the block's spatial structure and living surroundings (Fig. 16). A large scale building with the huge parking area dominates in the urban environment by occupying the space of the block; it deformed the perimetric housing that is typical of an old town structure. This is another example showing that in contemporary situations, aggressive business wins rather than the aspirations to preserve the urban spatial structure and identity.

Most of mid size towns have only about 10.000 15.000 population. Their spatial structure is much simpler with a less developed street network, one-two squares with administrative buildings and sacred objects. Most often, such towns are rather old (dating back to the

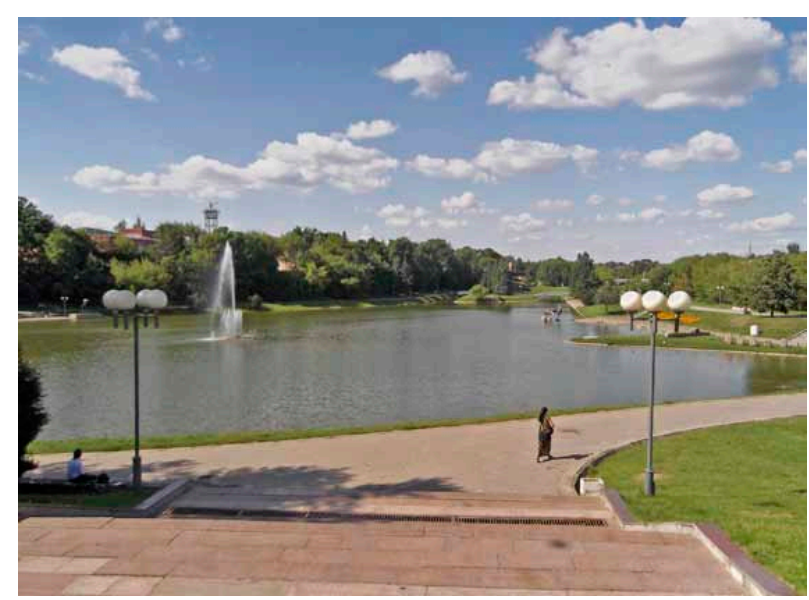

Fig. 15. A significant component of the spatial structure of the city of Panevezzys is the public space near the old watercourse of the river Nevezzis. It enriches townscape and creates its identity. L. Dringelis photo $13^{\text {th }}-15^{\text {th }}$ centuries) and located near the water bodies rivers and lakes. The city of Telšiai is most distinct in the mentioned group of the towns due to its original spatial structure, natural conditions and the interaction with the water body - the lake Mastis. It is the centre of the district. This town is specific for its public spaces are united with the space of the lake both from the functional and visual, compositional and aesthetic perspectives, which was achieved by forming the approaches to the lake and viewpoints (Fig. 17).

Among the mid-size towns the ones whose age reaches no more than 50-60 years should also be mentioned here, such as, for instance, Elektrenai and Visaginas. Due to their architecture these towns do not differ from other towns of new industrial construction. However, they may be interesting as the products planned and built by professional architects and reflect the level of the Soviet period of urban development (Figs 18, 19).

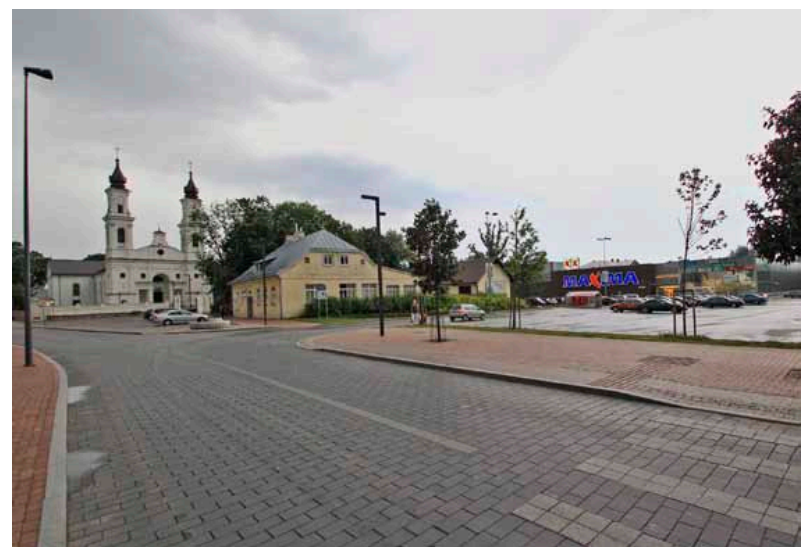

Fig. 16. As an unfriendly 'inclusion' integrated into an old part of the Marijampole town, the supermarket "Maxima" has destroyed the street network, the spatial structure and the scale ratio of the territory. E. Ramanauskas photo

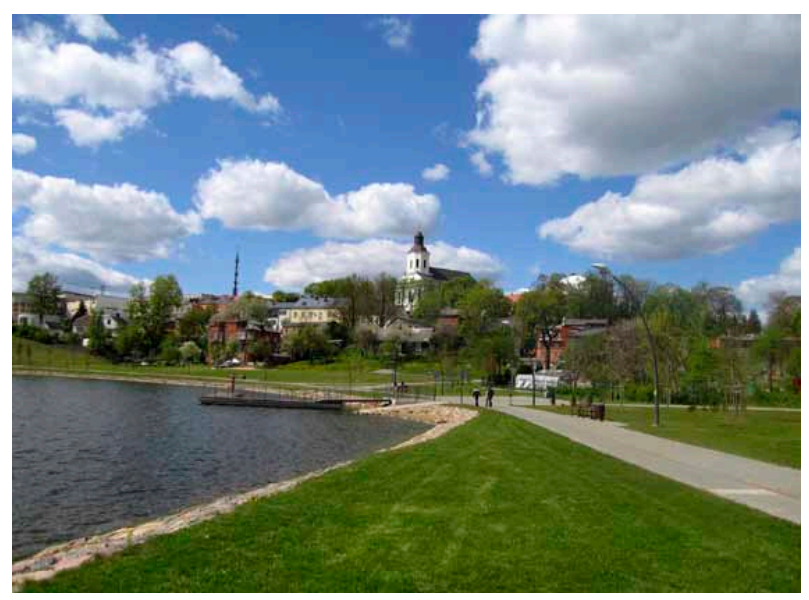

Fig. 17. The specific feature of the spatial structure of the town of Telšiai is its functional and visual connection with the space of the lake. E. Ramanauskas photo 


\section{Small towns}

Small towns make the greatest part of the Lithuanian towns $-70 \%$ or $68 \%$ from their total number (103). The size of such towns is from 3.000 to 10.000 population, yet, actually, the majority of the small towns ( $40 \%)$ do not reach 3.000 population, mostly about $1.000-2.000$ inhabitants. The larger towns of this group, similarly to the mid-size towns, in most cases are the centres of the district municipalities; the smaller ones are the centres of the elderships. Due to their character the municipality centres are most often the towns with 2-3 main streets and a square near the administrative buildings and with the space of an adequate shape near the sacred building. The spatial structure typically contains the church tower verticals, new 3-4 storey brick buildings in the town centres and old 1-2 storey wooden buildings (rarely the masonry ones) in other parts of the towns (Figs 20,21). The individuality of such towns as well as their specificity are marked by the particular natural conditions (terrain line, water

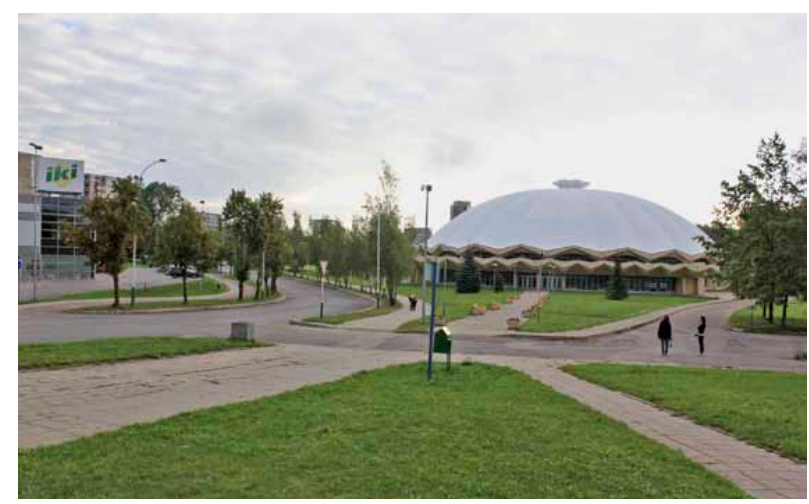

Fig. 18. Elektrenai is a new town whose identity is marked by its adjustment to natural conditions, i.e. hilly terrain line and water ponds, thus creating attractive urban interior spaces. E. Ramanauskas photo

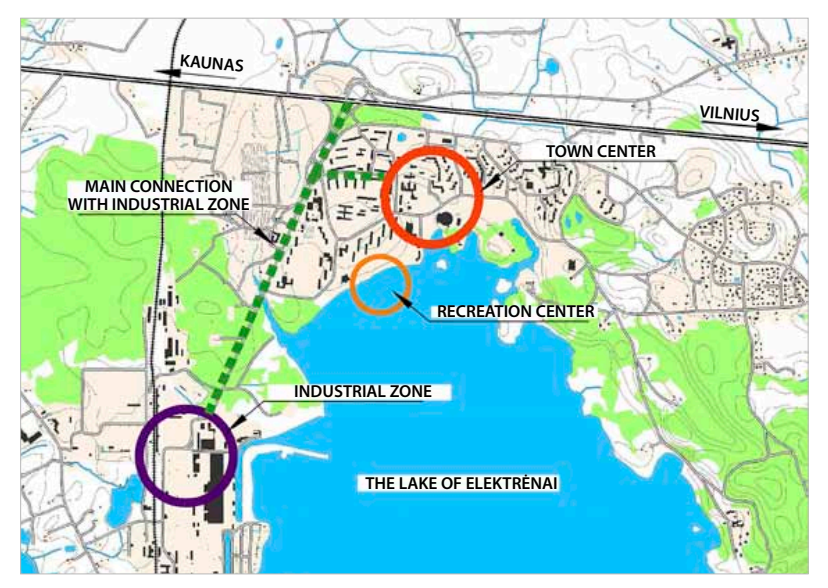

Fig. 19. The plan of the town of Elektrenai surfaces, green spaces) and the old parts of the towns (with specific street network, building arrangement, etc.). It should be noted that nearly in all the towns, larger or smaller, the water bodies are found - rivers, lakes, or ponds.

Similarly to townships, small towns are well conceived in the landscape, where their panoramas and silhouettes of the towers form a highly specific cultural landscape that is typical of Lithuania.

For the analysis of the problems related with the spatio-structural specificity of Lithuanian towns, it is important to discuss the specific characteristics of health resorts which make a distinct part of the settlements. There are four health resorts in Lithuania: Druskininkai, Palanga, Birštonas and Neringa. They are located in the areas of different natural conditions and hence have different purposes. Druskininkai is located in the pine forests, it has abundant recourses of mineral water and therapeutic mud, therefore its main function is balneologic and climatological treatment.

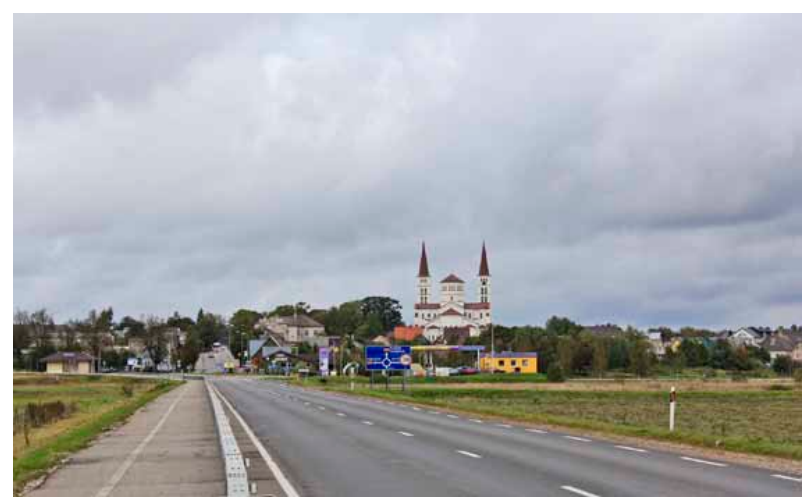

Fig. 20. A typical view of the small town: densely located buildings with a strong church dominant (the panorama of the Rietavas town). E. Ramanauskas photo

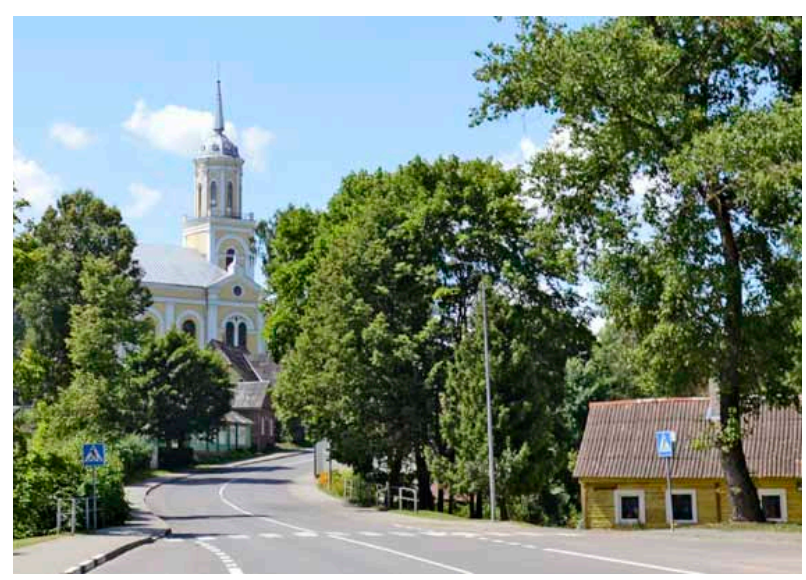

Fig. 21. An internal area of the small town (Kavarskas) with abundant greenery and a common 1 storey housing. I. Povilaitienè photo 
Birštonas health resort has analogical purposes. Other two health resorts, Palanga and Neringa, are sea resorts that offer climatological therapy and thalassotherapy treatment.

It should be stressed that these resorts grow very rapidly and are gradually changing by loosing their former identity - the harmony between nature and architecture, their housing design, scale and, most importantly, the spirit of the location. In the place of the former cozy and attractive resorts the huge commercial centers of recreational and leisure industries have been constructed; an intensive urban growth is being developed when valuable natural territories are built up with modern constructions and their preservation is neglected. It especially considers the Palanga and Druskininkai health resorts. These general considerations are based on the exploration of the spatiostructural specificity of health resorts that has been briefly introduced here due to the limited space of the paper.

\section{Townships, church villages and villages}

An exceptional group of the Lithuanian settlements contains townships, church villages, villages and settlements of single farm which belong to the category of rural settlements. The number of their population according to the accepted formal requirements is as follows: for townships - from 500 to 3.000 population; for church villages, villages and settlements of single farm up to 500 population. However, in reality, under such circumstances some villages reach more than 3.000 population and townships, in their turn, do not reach the limit of the accepted number of the population.

All the townships (about 249), church villages (301) and a part of villages (about 400 out of 19.000) having the objects of cultural and natural heritage have been included into the research of the Lithuanian settlements. The carried out analysis showed that both the townships and church villages, ordinary villages and settlements of single farm represent a different period, size and type of building arrangement related with the aims of the performed land reforms. In those regions of the country where the performed land reforms (resulting in the formation of the individual farms, collective farms (kolkhozes, etc.) did not reach a considerable extent, the old street strip villages or spontaneously formed villages have remained (Fig. 22). It is mainly observed in the woodlands, lands of low fertility and hilly territories which are located in the south-eastern and north-eastern parts of Lithuania. In other parts of Lithuania, the homestead villages and individual farms are found that emerged in the $18^{\text {th }}-19^{\text {th }}$ centuries. A rather significant period in the development of the spatial structure of the rural settlements is the Soviet collective land reform during which large settlements were formed. Such settlements were planned by professional designers who followed the imposed standards of the Soviet period (Butkevičius 1980). They demonstrate the tendencies of urban design (Fig. 23). Therefore the spatial structure of the rural settlements of each period (the Valakas type, individual farms, kolkhoz type, etc.) reflects the period's political, social and economic conditions and hence possess adequate specificity. For instance, the $18^{\text {th }}-19^{\text {th }}$ century traditions are reflected by the street strip villages which were built with wooden constructions on the strips of land distributed alongside a single street. The spatial structure of a homestead type village includes individual farms

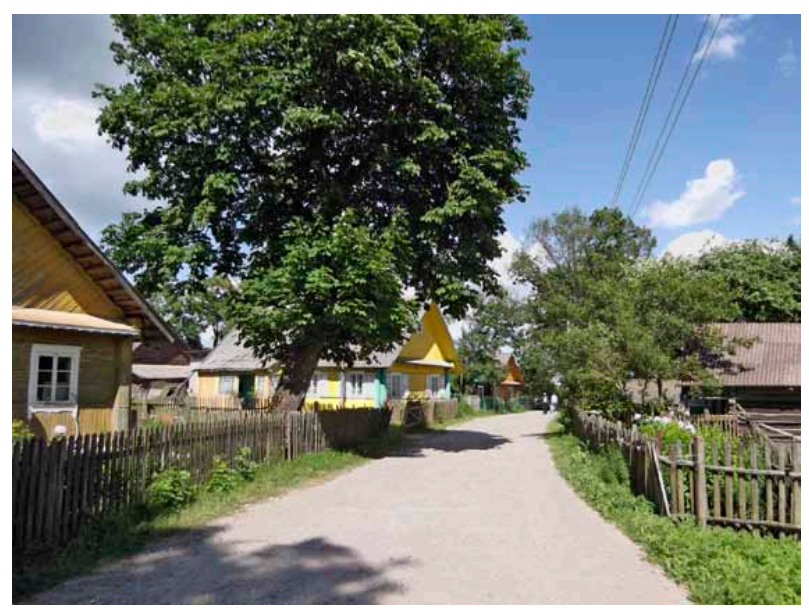

Fig. 22. The street perspective of the old Valakas type village whose street arrangement create spatial comfort and aesthetic appeal (the Žižmai village in the Šalčininkai district municipality). I. Povilaitienè photo

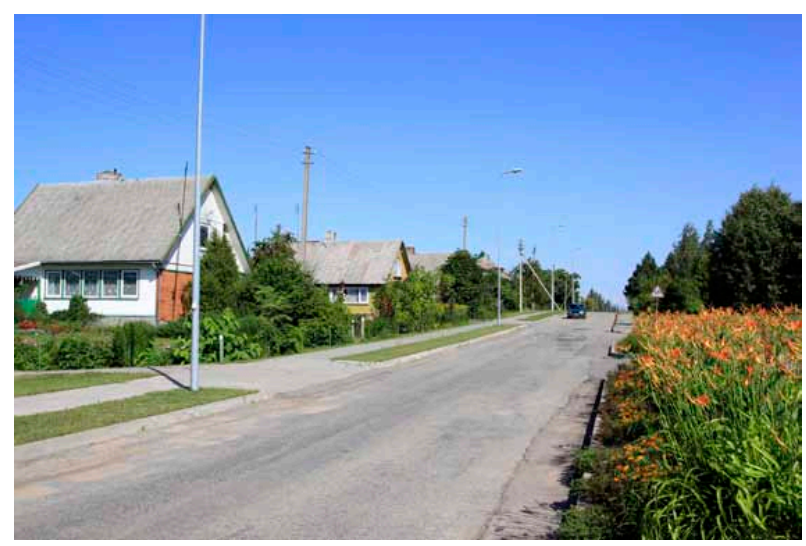

Fig. 23. A view of the newly formed Soviet type village. Gable roof architecture and green spaces cotinue the traditions of the Lithuanian rural settlements thus creating harmonious spatial structures in villages (the Kaulakiai village in the Raseiniai district municipality). E. Ramanauskas photo 
that are spontaneously located near the street or the road. The settlements of the kolkhoz type villages are of a more complex plan, they have public centres with administrative and shopping buildings, schools and kindergartens. Townships and church villages are most often the local centres containing a public square with the service buildings and the church located nearby or at some distance. Most often, in the small towns or church villages the church is located on the highest place of the relief and thus dominates in the area and functions as a very important and specific element of the spatial structure of the Lithuanian landscape (Fig. 24). It should also be stressed that old Lithuanian villages have semantic signs- crosses, are richly planted with greenery and melt into the surrounding natural environment (Fig. 25).

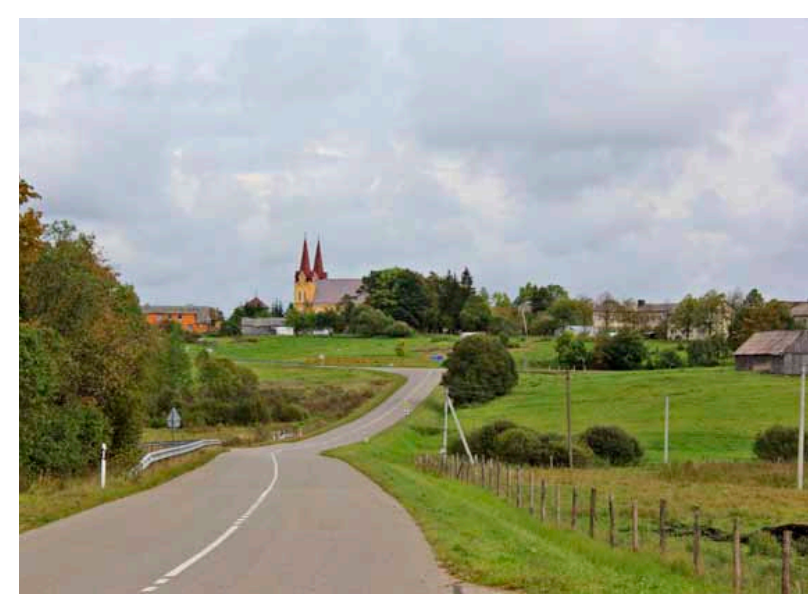

Fig. 24. Villages with church towers and rich greenery form the distinct components of the rural cultural landscape (the Medingènai church village in the Rietavas municipality). E. Ramanauskas photo

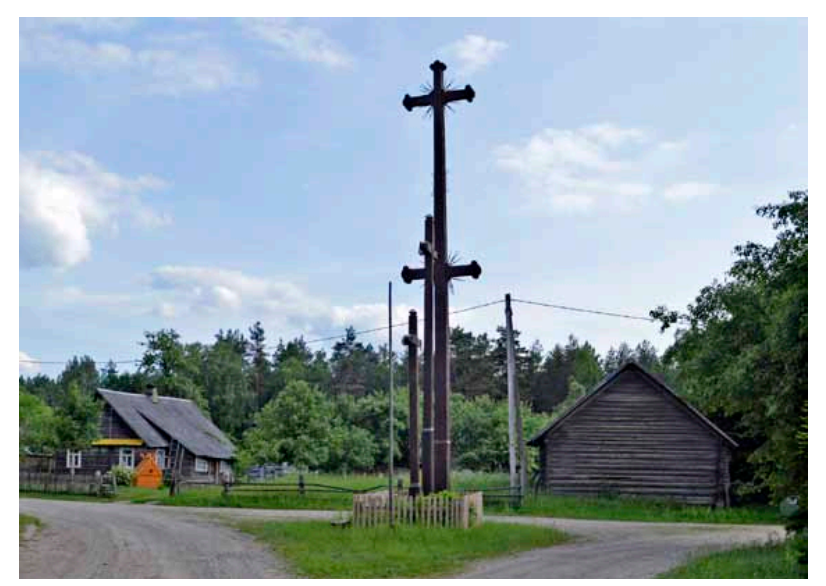

Fig. 25. Semantic signs - crosses form internal spaces of old Lithuanian villages (the Musteikos village in the Varèna district). I. Povilaitienè photo

\section{Characterization of the territorial location and spatio- structural specificity of lithuanian cities, towns, townships and villages in the context of European countries}

For the comparative analysis of the specificity of the spatial structure of the Lithuanian cities, towns, townships and villages in relation to the specificity of the settlements of other countries, the geographically close neighbouring countries have been selected, but the ones of a diverse population density (people per $\mathrm{km}^{2}$ ). To some extent, this index defines the type of the settling system of the analysed country, the size of the settlements, their concentration and landscape. As a country of low population density (47 people per $\mathrm{km}^{2}$ ) Lithuania is compared with other countries of similar population density: Latvia (35 people per $\mathrm{km}^{2}$ ) and Estonia (29 people per $\mathrm{km}^{2}$ ). The comparison is made with the countries of middle population density, such as Poland (123 people per $\mathrm{km}^{2}$ ) and Czech Republic (130 people per $\mathrm{km}^{2}$ ), and with the countries of high population density, such as Germany (231 people per $\mathrm{km}^{2}$ ). The research of the spatial structure of the mentioned countries was carried out on the basis of the cartographic material, the statistic data of the European countries, adequate scientific literature and with the use of up to date technologies worked out to explore the remote objects.

Such technological instruments allow for the possibility to obtain the following information about the analysed country: the territorial plan with the arrangement of the settlements and their size (Google Maps, Google Earth, Bing), the plans of the settlements with the street network and surrounding environment (Google Maps, Bing, Maps.lt), the statistic data about these areas (Citypopuliation.de) and visual information with the possibility to ascertain the height of the building up, the type of building material and architecture (Google Maps, Google Earth, Google Street Vew, Bing).

During the analysis of the spatial structure of the given settlements of the foreign countries and their type it was found out that not all of them offer the information on the same level, hence the detailed approach to the issue of the spatial specificity is not of the same level. For instance, very detailed information about the distribution of the settlements, their size and other features is given by Estonia and Czech Republic. However, some countries (e.g. Poland) give the topographic and other data only for the larger settlements and thus it is not possible to form a full view about the settling system of these countries, the 
size of the smallest settlements and other features. Nevertheless, despite the information gaps, certain differences between the spatial structures of the Lithuanian and foreign settlements have been determined and may serve as beneficial to describe the specificity of the spatial structure of the Lithuanian settlements.

\section{Territorial location of settlements}

The first features to be discussed are the distribution and size of the Lithuanian settlements. On the basis of the analysis of the general population and dwelling place census of 2001-2011 in Lithuania carried out by the Lithuanian Statistics Department it has been determined that each settlement of Lithuania approximately obtains $3.12 \mathrm{~km}^{2}$; in other words, the average distance between the settlements makes $2-3 \mathrm{~km}$. During the calculation of the density of the town settlements (103 towns and 249 townships) it has been determined that each town in Lithuania obtains $634 \mathrm{~km}^{2}$, which means that the average distance between the towns reaches $\sim 30-40 \mathrm{~km}$ and $10-15 \mathrm{~km}$ between the townships. Moreover, it should be noted that the Lithuanian cities, towns, townships and villages are rather small in their size, yet they occupy a dominant part in the country's settling system. For instance, small towns (with up to 3.000 population) make $38 \%$, and towns (with up to 10.000 population) make $68 \%$ from the total number of the Lithuanian towns. A similar situation is observed in the case of villages. Villages with the number of the population up to 10 inhabitants $(\sim 54 \%)$ dominate in the county, and the villages with up to 50 inhabitants make $83 \%$ from the total number of the Lithuanian villages. Hence from the given examples it may be observed that in Lithuania both towns and villages are of small scale, with a small number of the population and are evenly dispersively distributed in the territory of the country, which creates a certain specific character in comparison with the neighbouring countries. For further comparative analysis it is purposeful to discuss the specific character of the settling systems as well as the type of landscape in the context of Latvia, Estonia, Poland, Germany and Czech Republic.

Considering the fact that there is no possibility for a comprehensive detailed analysis of the towns and villages in the entire territory of the mentioned countries the authors limit themselves to the analysis of some particular regions which due to their distribution, natural conditions and type of settlement are similar to our country. Preliminarily, the comparative analysis concerns the Lithuanian towns in relation to the towns of Poland's Podlaskie province (voivodeship), the Pardubice region in Czech Republic, the federal lands of Mecklenburg - Vorpommern in Germany, the Zemgale province in Latvia and the Tartu district in Estonia.

The obtained data allowed to determine that each town in Poland (Podlaskie province) - obtains $505 \mathrm{~km}^{2}$, and the distance between them approximately makes $22 \mathrm{~km}$. The dominant size of the towns is up to 10.000 population which makes $\sim 64 \%$ from the total number of the towns in the province. Each town in the Pardubice region of Czech Republic obtains $129 \mathrm{~km}^{2}$, and the distance between the towns reaches $\sim 12 \mathrm{~km}$. The dominant size of the towns is up to 10.000 population which makes $\sim 72 \%$ from the total number of the towns located in the region. Each town in the federal lands of Mecklenburg - Vorpommern in Germany obtains $\sim 249 \mathrm{~km}^{2}$, and the average distance between the towns is $\sim 16 \mathrm{~km}$. The dominant size of the towns is up to 10.000 population and makes $~ 73 \%$ from the total number of the towns located in the federal lands. There is a rather dense village network in the mentioned territory, the distance between the villages reaching $\sim 6 \mathrm{~km}$. According to the existing data, the dominant size of the villages varies from 200 up to 1.000 inhabitants and makes $73 \%$ from the total number of the villages located here. In the Zemgale district in Latvia each town obtains 1.342 $\mathrm{km}^{2}$, and the distance between them is $\sim 40 \mathrm{~km}$, which shows the difference from other countries described above. The dominant size of the towns reaches up to 5.000 inhabitants whose number makes $~ 63 \%$ of the total number of the district's towns. Each rural settlement obtains $18 \mathrm{~km}^{2}$, and their dominant size is $\sim 200$ inhabitants. Such villages make $\sim 68 \%$ from the total number of the villages. A similar situation is observed both in Latvia and Estonia. In the Tartu district, each town obtains $\sim 998 \mathrm{~km}^{2}$, each small town $\sim 125 \mathrm{~km}^{2}$ and each village $\sim 9 \mathrm{~km}^{2}$. The average distance between the towns is $\sim 32 \mathrm{~km}$, between the townships $\sim 11$ $\mathrm{km}$ and between the villages $\sim 3 \mathrm{~km}$. The dominant size of the towns is up to 500 inhabitants and makes $50 \%$ and of the villages it is up to 100 inhabitants and makes $73 \%$ from the total number of the district's settlements.

Relying on the given analysis it may be claimed that due to the type of the settling system, the distribution and size of the settlements, Lithuania occupies an intermediate position among the countries of high and middle density (e.g. Germany, Czech Republic, Poland) and the countries of low density (Latvia and Estonia). The town network in Germany and especially in Czech Republic is dense. They are distributed at approximately $10-20 \mathrm{~km}$ distance from each other. The dominant size of the towns is up to $10.000 \mathrm{popu}-$ lation which makes $\sim 60-70 \%$ from the total number 
of the towns of the mentioned countries. To say more, this settling system is supplied with the distribution of the rural living areas, the dominant size of which is from 200 to 500 inhabitants. Such settlements make $\sim 60-70 \%$ from the total number of the villages.

Another situation is observed in Latvia (the Zemgale province) and Estonia (the Tartu district). Here the town network is sparse (the difference between them reaches about $30-40 \mathrm{~km}$ ) and their average size makes about 5.000 population. Rural living areas dominate in these countries, i.e. townships and villages whose average size is from 20 to 200 inhabitants. The distance between these settlements approximately makes $3-4 \mathrm{~km}$.

Thus, the comparative analysis of the distribution and size of the Lithuanian settlements and the country's settling system in relation to the distribution of the settlements and their size in the mentioned foreign countries shows that Lithuania differs from other countries by its individual specificity.

\section{Spatial structure of settlements}

What concerns the spatial structure, the type of building up, the type of plan and other features, it should be noted that differences between Lithuania and the neighbouring countries have been observed. The most distinct ones have been found between the building arrangement and architecture of the Lithuanian towns and townships, and the towns and townships of Germany and Czech Republic. The 3-4 storey masonries with tiled roofs form the perimeter type of the building arrangement typical of the Medieval towns dominate in the towns and townships of the discussed regions in the mentioned countries, especially in the historical centres. In the peripheral regions of the towns and in the townships the perimeter building arrangement of 1-2 storey masonries or farmsteads dominates. In the Lithuanian towns and townships the mixed type of building arrangement is most frequently observed: 3-4 storey and higher brick buildings dominate in the central part of the towns; further away from the town centre, 1-2 storey brick and wooden buildings prevail. In most cases, the townships are built up with 1-2 storey wooden constructions. The brick buildings appeared only in such townships which were constructed in the Soviet period. The types of the building arrangement and architecture in the Polish towns and townships are more similar to those of our country than it has been noticed in Germany and Czech Republic. It is so, most probably, both due to the similar natural conditions and neighbourhood contacts, which had an obvious effect on the planning and building arrangement of the settlements. Therefore in the discussed province of Poland, as in Lithuania, the wooden constructions are dominant, especially in the smaller towns and townships. The comparison of the Lithuanian cities, towns, townships and villages with the similar settlements in Latvia and Estonia showed that both in the planned structure and the building arrangement the essential differences nearly do not exist. In the mentioned neighbouring countries, as in the case of Lithuania, the dominant building arrangement of the urban centres is 3-4 storey brick buildings; meanwhile in the townships and villages 1-2 storey wooden and brick farmstead buildings are found. It should be stressed that more distinct differences between the countries have been observed in architecture, since Lithuania was affected by the Italian and French styles; meanwhile Latvia and Estonia were more influenced by German architectural tendencies.

To sum up, it might be claimed that the distinct specificity of the Lithuanian settlements in comparison with the specific features of the settlements in other analysed countries has been firstly observed in the cities which are unique. The originality and identity of our country is expressed in smaller towns, townships and church villages with the 1-2 storey wooden buildings whose most important dominant is the church. It forms both the interior spaces with the square and other public buildings and a specific panorama and silhouette of the settlement as a highly valuable component of the spatial structure of the country's urban cultural landscape. The old Valakas-type villages and later villages are especially significant areas representing the identity of Lithuania with their adequate street design, wooden construction arrangement, architecture, cosy interior spaces with particular semantic signs - crosses, chapel-posts, roofed posts and other memorable symbols and rich green plantation spaces form an exceptional Lithuanian rural landscape.

The carried out research initiated the following important essential problem: firstly, how to determine, estimate and legitimatize the most significant specific features of the cities, towns, townships and villages and, secondly, how to protect and preserve them. To fulfill such an aim, the formation of an adequate legislate basis is urgent, in which the requirement for the protection and preservation of the specificity of the spatial structure of the settlements in territorial planning would be compulsory.

\section{Conclusions}

1. In order to determine the specificity of the spatial structure of the Lithuanian cities, towns, townships and villages all the towns (103), townships (249) and a part of the rural living areas (716 out of 20.691) 
possessing cultural and natural heritage have been selected for research. The total number of the analysed objects makes 1.068 , or $5 \%$ from the total number of the country's settlements (21.043).

2. The indoor research and field exploration of the spatial structure of the selected Lithuanian cities, towns, townships and villages has been performed. During research the period of the settlements' construction has been determined and the following aspects described: natural conditions, plan type and spatial structure, housing arrangement, highly significant buildings and constructions (sacred, public, etc.). distinguished.

3. The carried out analysis showed that all the Lithuanian cities (four in all) have a distinct specificity due to their planned and spatial structure, natural conditions and architecture, and semantic signs typical of each city. Among them, Vilnius is the most distinct, being also internationally recognized as a unique city.

4. Mid-size towns (about 29), first and foremost, differ in their size and spatial structure. The ones whose number of the population ranges from 30.000 to 50.000 and more, approach the character of the large towns by their spatial structure, the number of squares and other public spaces, their housing arrangement and by containing public and sacred buildings. Contrariwise, the mid-size towns whose number of population is only about $10.000-15.000$ reflect the traditional type of the small towns: they have an ordinary street network of 3-4 main streets, a representational square with administrative and commercial buildings, a sacred building and an adequate green square.

5. According to their planned and spatial structure, small towns (about 70) have the street network of 2-3 main streets, their building arrangement is of two types - a new settlement of 2-3 storey brick buildings; an old settlement with 1-2 storey mixed type building arrangement. They have a public urban space with a square and its administrative and shopping buildings, a church and a green space. Such towns are to some extent similar and form an adequate type of urban spatial structure. The differences between them, if they do occur, are most frequently determined by natural conditions, the quality of visibility, panoramas, etc.

6. Townships (around 249), church villages (about 301) and ordinary villages belong to the category of rural living areas. Due to their status, period of formation and other factors they differ by their spatial structure, building arrangement and functions. Townships and church villages, which in most analysed cases are administrative centres, have a similar spatial and planned structure. As a rule, it contains 1-2 main streets, a square, or street expansion near the buildings of administrative, public or sacred function, and the like. Villages that were under the influence of several land reforms and reorganizations have different spatial structures. The oldest ones are scarcely preserved street strip villages; the same might be said about homestead villages. The latest type of villages is the kolkhoz type. They were designed by professional architects according to the imposed standard requirements of the Soviet period. This again confirms that the spatial structure of the villages representing different periods creates their specificity and identity and hence should be protected.

7. The comparative analysis of the spatial and planned structure of the Lithuanian cities, towns, townships and villages in relation to the analogical objects in some neighbouring countries (Poland, Czech Republic, Germany, Latvia and Estonia) revealed the distinct specificity of our country's settlements which is formed by: the density of their distribution in their territory, their small scale, the size of the cities, towns, townships and villages, the character of their building arrangement, architecture, building materials, green plantation spaces, formation of public spaces with the specific semantic signs.

8. In order to protect and foster the specificity of the spatial structure of the Lithuanian cities, towns, townships and villages, first and foremost, it is urgent to legitimatise the specific features representing their identity - natural, landscape, urban, architectural, aesthetic, visual, etc. This requires the improvement of the legislate and standard base which should include the requirements to perform an estimation of the specificity of the settlements before working out the plans of their design and to provide the means for the preservation of the determined identity.

\section{Acknowledgement}

The research represented in this article was financed by Research Council of Lithuania. Agreement No VAT-60/2012.

Translated from Lithuanian by Jadvyga Krūminienè.

\section{References}

Alexander, Ch. 2002, 2012. The nature of order. Book 1. Berkeley, California: The Center for Environmental Structure.

Bardauskienè, D. 2006. Vilniaus miesto savitumas - Europos sąjungos kontekste, Vilniaus miesto savitumai. Konferencijos pranešimai. Vilnius: Vilniaus dailès akademijos leidykla, $17-28$. 
Basalykas, A. 1977. Lietuvos TSR kraštovaizdis. Vilnius: Mokslas.

Benevolo, L. 1998. Europos miesto istorija. Vilnius: Baltos lankos.

Bučas, J. 2001. Kraštotvarkos pagrindai. Kaunas: Technologija.

Bučas, J. 1988. Lietuvos kaimo kraštovaizdžio raida ir istorinès vertybes. Vilnius: Mokslas.

Butkevičius, I. 1971. Lietuvos valstiečiu gyvenvietes ir sodybos. Vilnius: Mintis.

Butkevičius, I. 1980. Lietuvos socialistinio kaimo gyvenviečiu formavimasis. Vilnius: Mokslas.

Cullen, G. 1961. The concise townscape. London: The Architectural Press.

Čepaitienè, R. 2006. Kultūros paveldas ir lietuviškasis tapatumas. Kultūros paveldas ir visuomenè XXI a., nacionaliniai ir tarptautiniai aspektai. Vilnius: Vilniaus dailès akademijos leidykla ir spaustuve, 111-118 p.

Daniulaitis, G. 2001. Miestovaizdžio samprata ir jo tyrimų poreikis, Konferenciju pranešimo medžiaga: Kultūriniu kraštovaizdžiu apskaita ir apsauga. Kaunas: Technologija.

Daniulaitis, G. J. 2003. Miestovaizdis ir jo projektavimas. Urbanistika ir architektūra XXVII(1): 3-11. Vilnius: Technika.

Daujotaite, I. M. 2006. Vilniaus gamtinè morfostruktūra miesto urbanistinè savastis, Vilniaus miesto savitumai. Konferencijos pranešimai. Vilnius: Vilniaus dailès akademijos leidykla, 41-47.

Daunora, Z. J. 2004. Istorinių miestų vizualinio įvaizdžio plètojimo klausimu. Urbanistika ir architektūra XXVIII(4): 145-150. Vilnius: Technika.

Daunora, Z. J.; Kirvaitienė, S.; Vyšniūnas, A. 2004. Vilniaus miesto vizualinio identiteto apsauga ir pletros principai. Vilnius: Technika.

Drèma, V. 1991. Dingęs Vilnius. Vilnius: Vaga.

Dringelis, L. 2013. Lietuvos miestai, miesteliai ir kaimai: jų urbanistinių ir demografinių pokyčių it taka šalies kraštovaizdžio erdvinès struktūros savitumui, Journal of Architecture and Urbanism 37(4): 310-323.

http://dx.doi.org/10.3846/20297955.2013.869884

Grecevičius, P.; Marčius, R. 2006. Rekreacinio kraštovaizdžio erdvinès struktūros formavimo strategijos aspektai stiprinant Lietuvos kultūrinị identitetą baltijos šalių kontekste, Urbanistika ir architektūra XXX(2): 87-96. Vilnius: Technika.

Europos arhitektūros paveldo apsaugos konvencija (Grenada, 1985). Kultūros paveldo apsauga. Reglamentuojančių dokumentu rinkinys. Vilnius: Savastis, 76-84.

Europos architektūros paveldo chartija (Amsterdamas, 1975). Kultūros paveldo apsauga. Reglamentuojančių dokumentų rinkinys. Vilnius: Savastis, 114-126.

Europos arheologijos paveldo apsaugos konvencija (Valeta, 1992). Kultūros paveldo apsauga. Reglamentuojančiu dokumentu rinkinys. Vilnius: Savastis, 99-106.

Europos kraštovaizdžio konvencija (Florencija, 2000). Susiję dokumentai. 2012. Vilnius: Lietuvos Respublikos aplinkos ministerija.

Europos urbanistikos chartija (Strasbūras, 1992). Europos spaudos taryba [interaktyvus] Europos Taryba, [žiūrèta 2014 m. spalio 22 d.]. Prieiga per internetą: https://wcd.coe. int/ViewDoc.jsp?id=887405\#P12_318
Jakovlevas-Mateckis, K. 2008. Miesto kraštovaizdžio architektūra, I tomas. Vilnius: Technika.

http://dx.doi.org/10.3846/1446-M

Jakovlevas-Mateckis, K. 2011. Miesto kraštovaizdžio architektūra, II tomas. Vilnius: Technika. http://dx.doi.org/10.3846/1913-M

Jakovlevas-Mateckis, K. 2014. Miesto kraštovaizdžio architektūra, III tomas. Vilnius: Technika. http://dx.doi.org/10.3846/2153-M

Lietuvos Respublikos kraštovaizdžio politikos krypčiu aprašas. Patvirtintas 2004-12-01 Lietuvos Respublikos Vyriausybės nutarimu Nr. 1526 (Žin., 2004, Nr. 174-6443; 2005, Nr. 64-2302).

Lynch, K. 1960. The image of the city. Cambridge, Massachusetts: MIT press.

Mačiulis, A. 2006. Vilniaus miesto savitumas: gamtos ir architektūros darna, Vilniaus miesto savitumai. Konferencijos pranešimai. Vilnius: Vilniaus dailès akademijos leidykla, 7-16.

Minkevičius, J. 2005. Lietuvos kraštovaizdis kaip tautos dvasios formantas, Lietuvos kraštovaizdžio vizija. Konferencijos pranešimu medžiaga. Kaunas: Technologija.

Minkevičius, J. 2014. Prieštaringoji architektūra. Kaunas: Naujasis lankas.

Miškinis, A. 1991. Lietuvos urbanistika: istorija, dabartis, ateitis. Vilnius: Mintis.

Miškinis, A. 1999. Lietuvos urbanistikos paveldas ir jo vertybès, I tomas. Užnemunès miestai ir miesteliai. Vilnius: Petro ofsetas.

Miškinis, A. 2002. Lietuvos urbanistikos paveldas ir jo vertybes, II tomas. Rytų Lietuvos miestai ir miesteliai. 1 knyga. Vilnius: Savastis.

Miškinis, A. 2005. Lietuvos urbanistikos paveldas ir jo vertybess, II tomas. Rytų Lietuvos miestai ir miesteliai. 2 knyga. Vilnius: Savastis.

Miškinis, A. 2004. Lietuvos urbanistikos paveldas ir jo vertybès, III tomas. Vakarų Lietuvos miestai ir miesteliai. 1 knyga. Vilnius: Savastis.

Miškinis, A. 2007. Lietuvos urbanistikos paveldas ir jo vertybès, III tomas. Vakarų Lietuvos miestai ir miesteliai. 2 knyga. Vilnius: Savastis.

Miškinis, A. 2009. Lietuvos urbanistikos paveldas ir jo vertybes, IV tomas. Vidurio Lietuvos miestai ir miesteliai. Vilnius: Petro ofsetas.

Moughtin, C. 1999. Urban design: street and square. Oxford: Architecturtal Press.

Pasaulinio kultūros ir gamtos paveldo globos konvencija (Paryžius, 1972). 2006. Vilnius: Lietuvos nacionalinė UNESCO komisija.

Petrušonis, V. 2002. Vietovès kultūrinio tapatumo subjektinis substratas, Urbanistika ir architektūra XXVI(1): 18-36. Vilnius: Technika.

Petrušonis, V. 2010. Kultūrinio konteksto reikšmè vertinant architektūrinị kompleksą, Urbanistika ir architektūra 34(5): 252-261. Vilnius: Technika.

Purvinas, M. 2011a. Rytų Lietuvos kaimu istoriné raida. I knyga. Kaunas: Technologija.

Purvinas, M. 2011b. Mažosios Lietuvos etnografiniai kaimai. Trakai: Voruta.

Purvinas, M. 2013. Mažosios Lietuvos kaimu istorinè raida. I knyga. Kaunas: Technologija. 
Rubavičius, V. 2005. Miesto tapatumas ir išskirtinumas globalizacijos sąlygomis, Urbanistika ir architektūra XXIX(4): 157-163. Vilnius: Technika.

Salingaros, N. A. 2006. A theory of architecture. Solingen, Germany: Umbau-Ferlag.

Samalavičius, A. 2013. Miestas ir protas: urbanistinès teorinès refleksijos XX a. vakaruose. Vilnius: Technika. http://dx.doi.org/10.3846/2119-M

Stauskas, V. 2012. Architektūra, aplinka, atostogos. Kaunas: Vytauto Didžiojo universitetas.

Šešelgis, K. 1988. Lietuvių liaudies architektūros paminklai III. Savaimingai susiklostę kaimai. Vilnius: Mokslas.

Šešelgis, K.; Urbelis, M. 1980. Lietuviu liaudies architektūros paminklai II. Maži padriki kaimai Lietuvos TSR nacionaliniame parke. Vilnius: Mokslas.

Tatoris, J. 1994. Senoji Klaipéda. Vilnius: Mokslo ir enciklopediju leidykla.

Vanagas, J. 2006. Vilniaus miesto savitumai ir viena jo teritorinès plètros alternatyvų, Vilniaus miesto savitumai. Konferencijos pranešimai. Vilnius: Vilniaus dailès akademijos leidykla, 29-39.

Vilniaus miesto savitumai. 2006. Konferencijos pranešimai. Sud. Algimantas Mačiulis. Vilnius: Vilniaus dailès akademijos leidykla.

Zaleckis, K.; Kamičaitytė-Virbašienė, J.; Ramanauskas, E. 2013. Kauno miesto identiteto formantų išsaugojimo galimybès planuojant miesto vystymąsi, iš VII Urbanistinis forumas. Miestas ir vanduo, 42-46 [interaktyvus], [žiūrèta $2014 \mathrm{~m}$. spalio 22 d.]. Prieiga per internetą: http://ktu.edu/saf/sites/ ktu.edu.saf/files/bylos/Leidiniai/uf_leidinys_2014g.pdf

\section{LIUCIJUS DRINGELIS}

Doctor of the Humanities (1983) (Arch.) - Senior Researcher of the project, Institute of Architecture and Construction of Kaunas University of Technology, Centre for Territory planning

Tunelio g. 60, Kaunas 44405, Lithuania.

E-mail: liucijus.dringelis@ktu.lt

Research interests: landscape architecture and planning of health resorts, planning of recreational and green areas, urban planning, land-use management, cultural heritage.

\section{EVALDAS RAMANAUSKAS}

Doctor of the Humanities (2011) (Arch.) - Researcher of the project, Institute of Architecture and Construction of Kaunas University of Technology, Centre for Territory planning, Tunelio g. 60, Kaunas 44405, Lithuania.

E-mail: evaldas.ramanauskas@ktu.lt

Research interests: territorial planning, landscape research, cultural heritage research, architectural design.

\section{INGRIDA POVILAITIENE்}

Architect of the project, Institute of Architecture and Construction of Kaunas University of Technology, Centre for Territory planning, Tunelio g. 60, Kaunas 44405, Lithuania.

E-mail: i.lipnickyte@gmail.com

Graduated from Kaunas University of Technology in 2012. Research interests: urban planning, visual urban identity of cities and towns.

\section{JUSTINA MAČIUKĖNAITE்}

Architect of the project, Institute of Architecture and Construction of Kaunas University of Technology, Centre for Territory planning, Tunelio g. 60, Kaunas 44405, Lithuania.

E-Mail: justina.maciukenaite@gmail.com

Graduated from Kaunas University of Technology in 2010. Research interests: urban planning. 